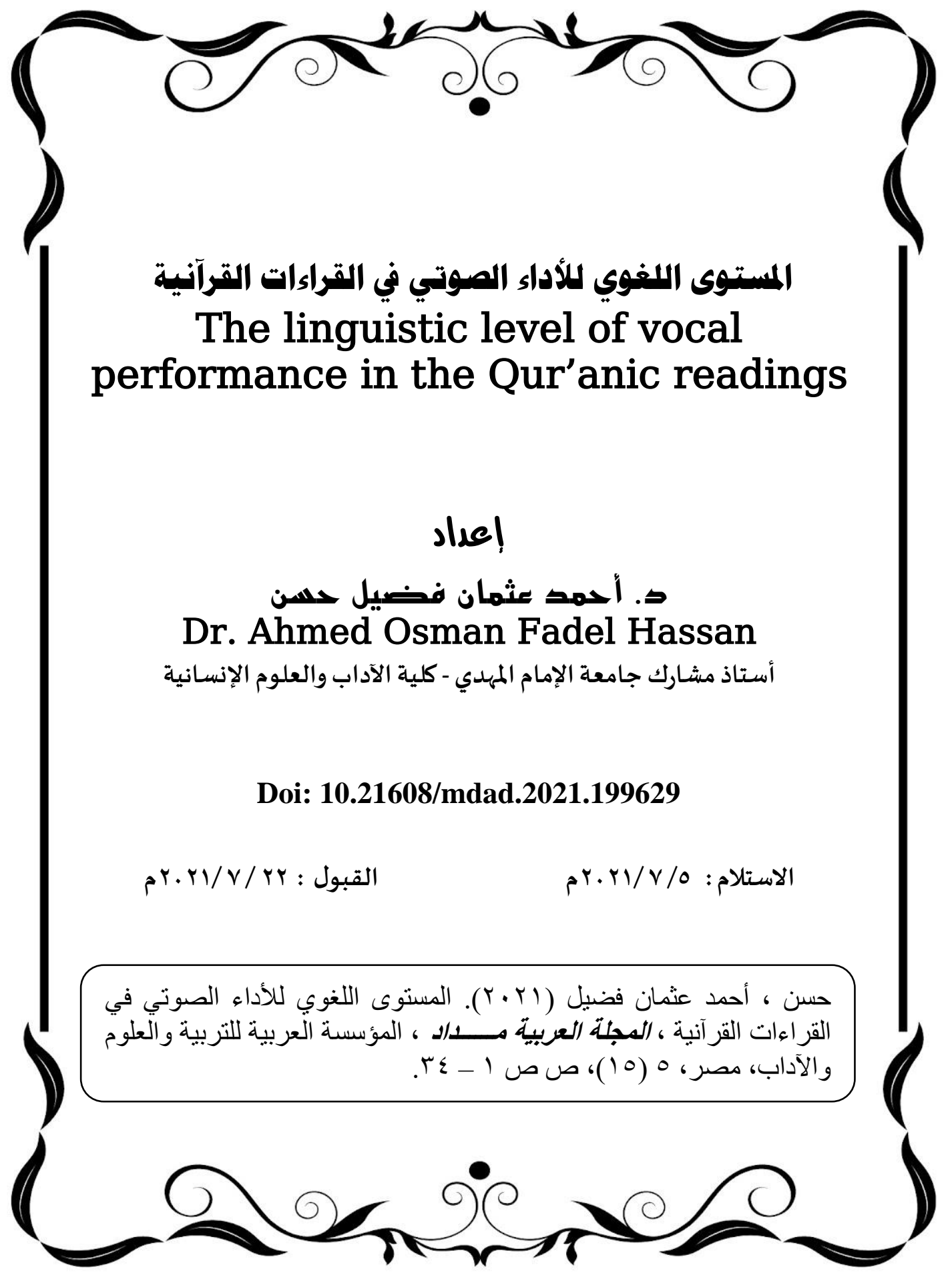




\section{المستوى اللغوي للأداء الصوتي في القراءات القرآنية}

يهدف هذا البحث إلى إبراز القيمة اللغوية للقراءات القرآنية وذللك من خلال الأداء

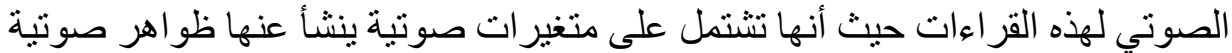

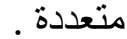

يشتمل هذا البحث على المحاور الآتية :

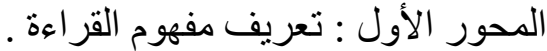

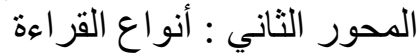

المحور الثالث : الظواهر الصوانوتية في القراءات القرآنية ثم الخاتمة .

\section{Abstract:}

This research aims to highlight the linguistic valve of Kovanic reading thorough the avdio performance of these readings as they include voice variable genesis of her multiple a vdio phenomena .

The research includes the followings :

Fivet point : the definition of the concept of reading .

Second point : types of readings .

Third point : A covstic phenomena in the readings .

And conclusion \& findings and recommendations

اختلفت آراء علماء المسلمين حول القراءات القرآنية ، فمنهم من قال بتواترها

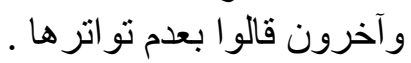

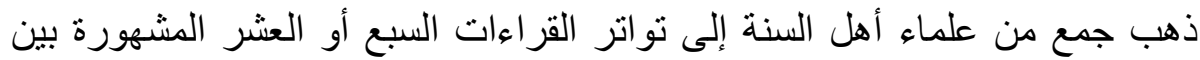

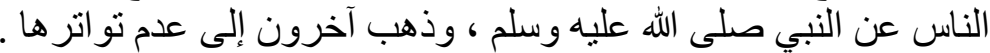

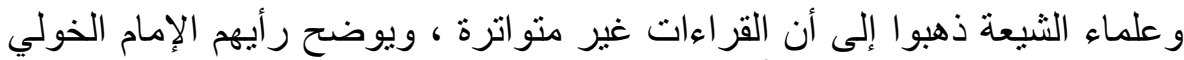

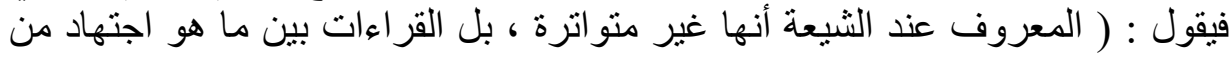

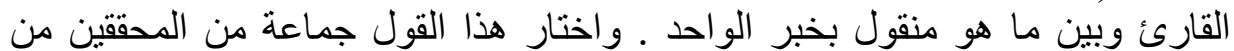

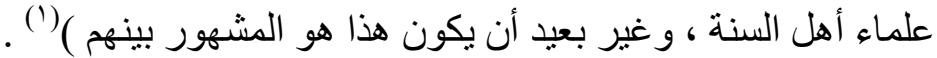
ويعني ذلك أنّ علماء المسلمين لم يتفقو اعلى تو اتر القر اءات القر آنية .

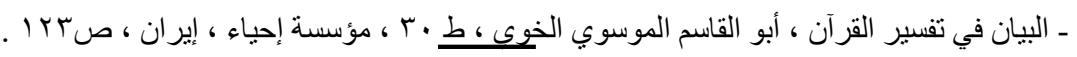


أما القرآن ذاته فلم يختلف المسلمون في أنه ينحصر طريق ثبوته و الحكم بأنه كلام

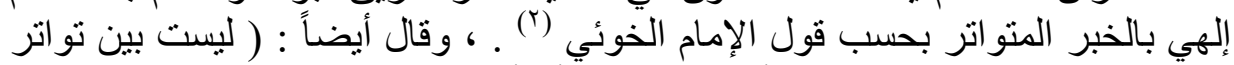

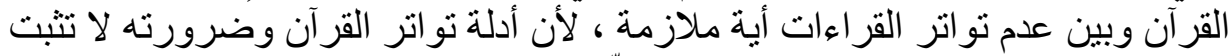

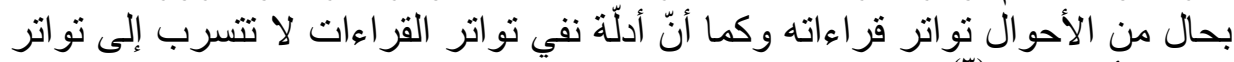

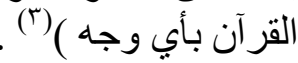

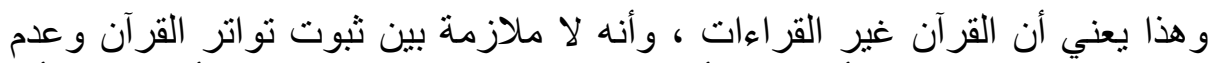

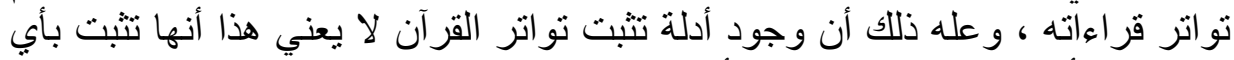

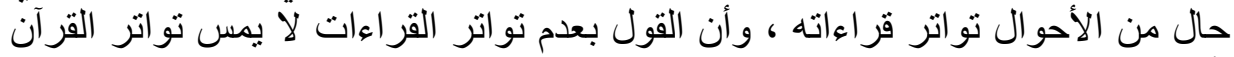

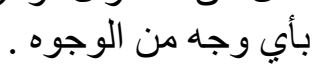

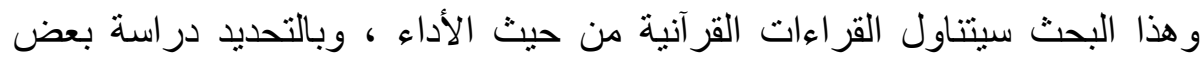

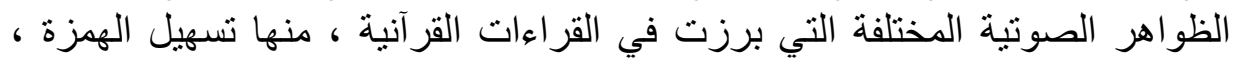

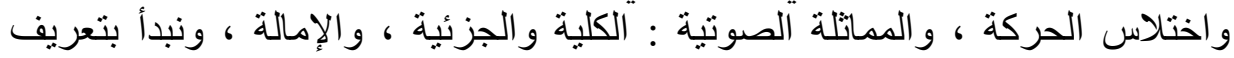
القر اعة .

\section{المبحث الأول}

\section{تعريف مفهوم القراعة}

\section{معنى القراعة}

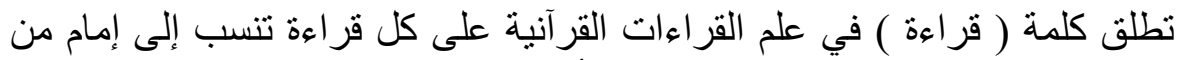

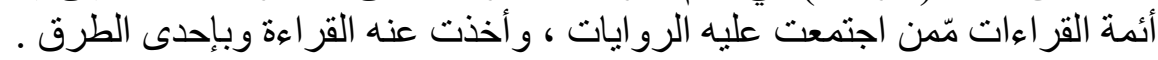

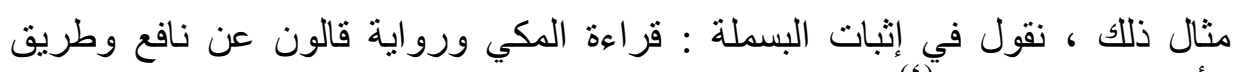

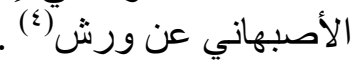

ويعني بالرو اية : ما نسب للآخذ عن لقارئ ولو بوساطة . و الراوي هو حامل الرواية أو ناقلها .

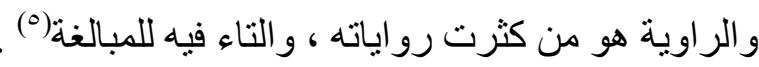
و الطريق هو ما ينسب لمن أخذ عن الرواة ولو سفل .

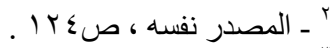

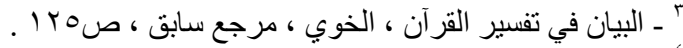

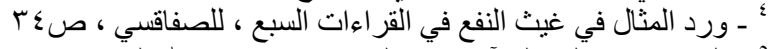

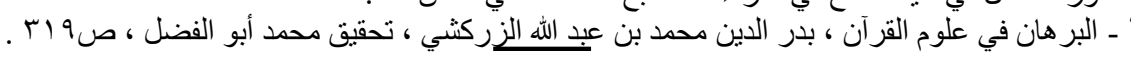


ولكل إمام صاحب قر اءة رواة كثثبرون قد رووا عنه ، ويوجد راو طرق متعددة .

علم القراءات

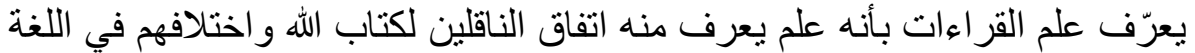

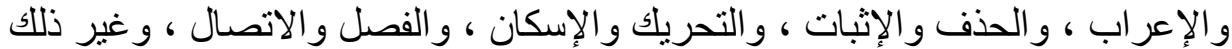

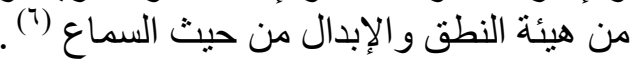

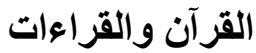

اختلفت نظرة العلماء نحو القراءات ، فمنهم من عدّها قر آناً مُنز لاً من عند الله ، ومنهم

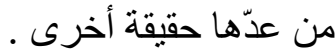

فمن الفريق الأول الباقلاني إذ يرى أن القراءات قرآن منزل من عند الله اله تعالى ، و وأنها

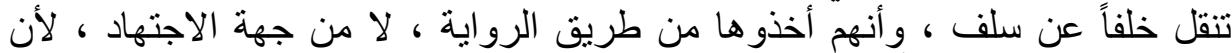

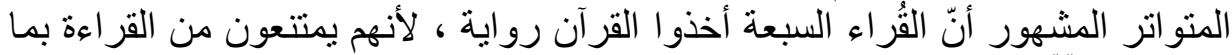
لم لم يسمعوه (v)

و ون الفريق الثاني الزركشي ، إذ عدّ القراءات حقيقة أخرى غير حقيقة القرآن فقال :

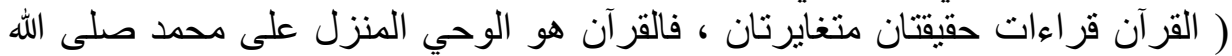

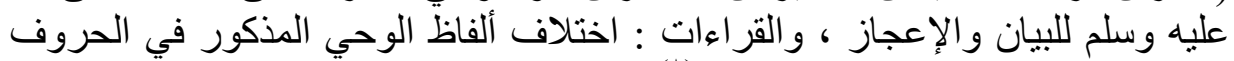

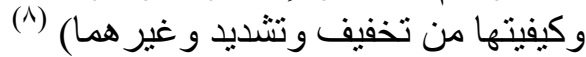

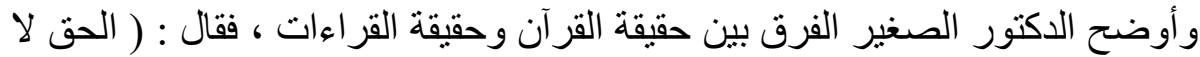

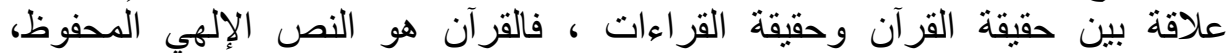

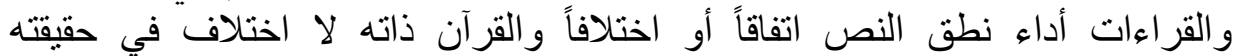

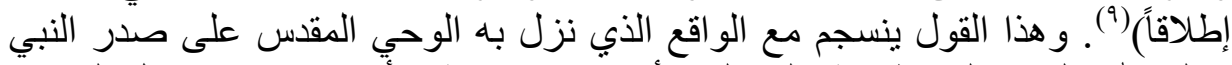

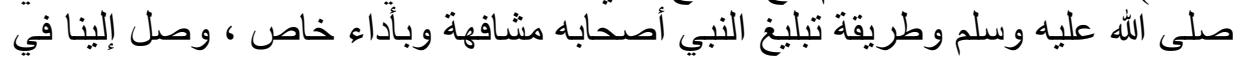

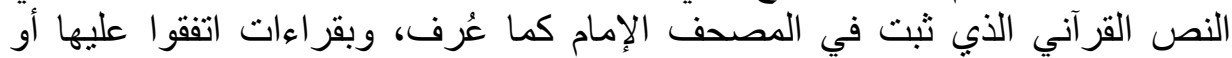
اختلفو ا فيها. ويؤيد هذا ما روى عن النبي صلى الله عليه وسلم: ( اقرعوا كما علمتكم ) وقد ردده

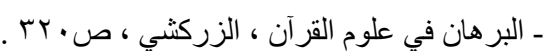

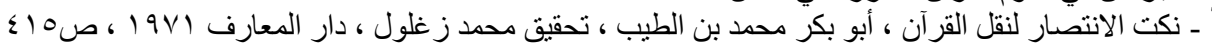

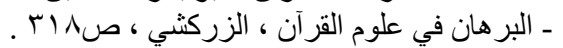

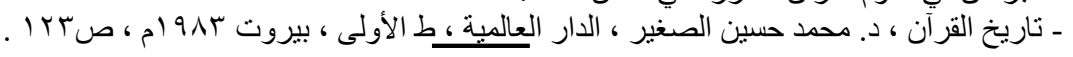


الإمام الصادق)(·() . وعرض الثيخ الطوسي (ت. .7؟هـ) رأي الإمامية حول هذه

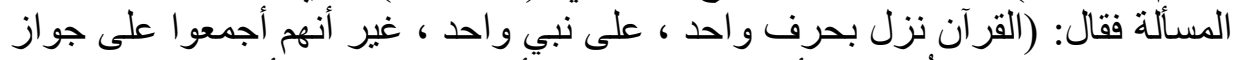

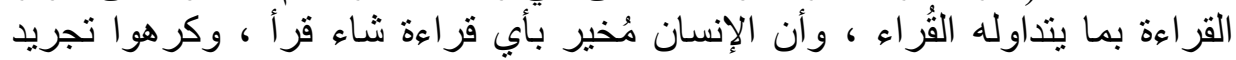

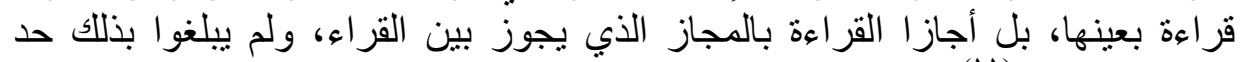

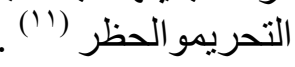

تشأة القزاعات

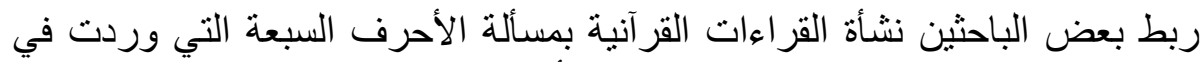

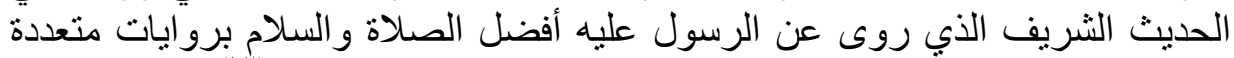

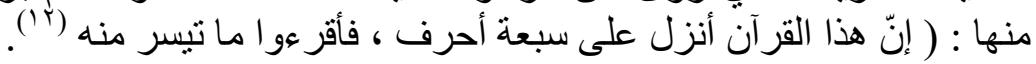

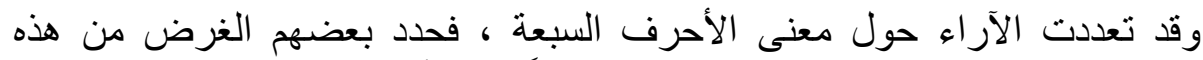

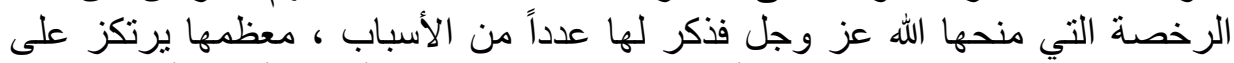

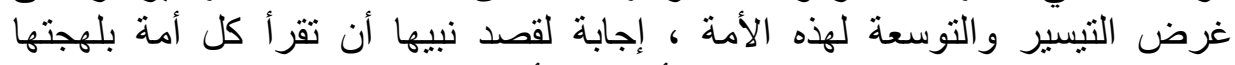

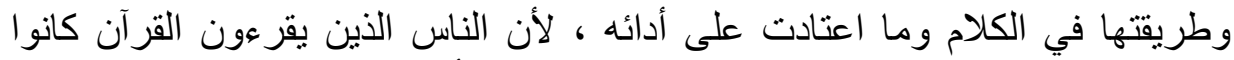

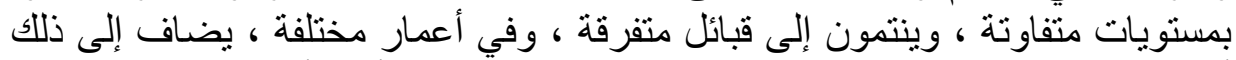

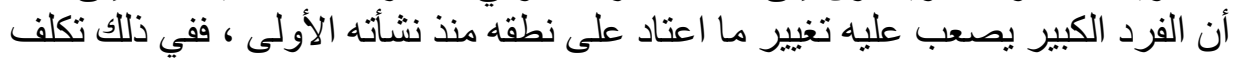

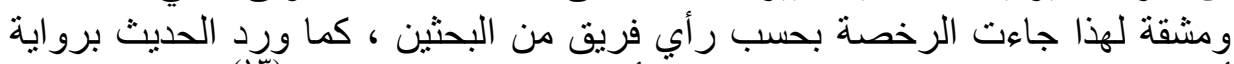

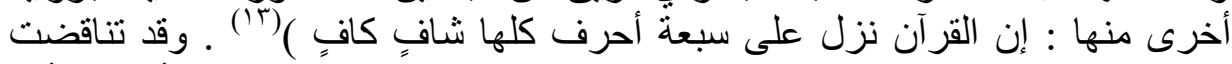

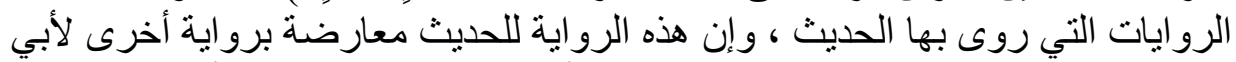

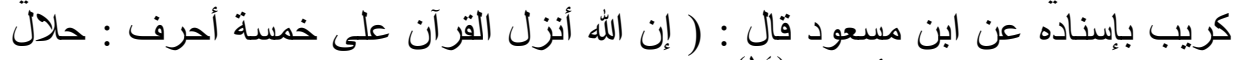

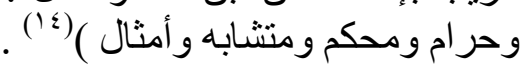

$$
\text { و اختلفو ا في تأويل معنى ( الأحرف ) وتأويل العدد ( سبعة ). }
$$

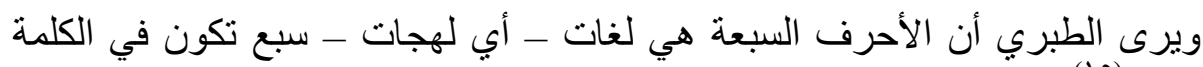

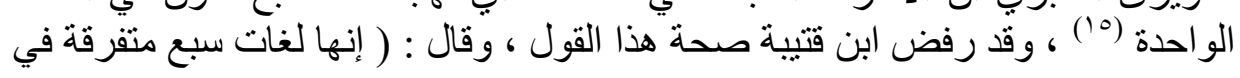

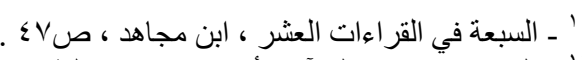

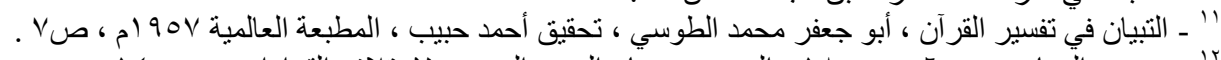

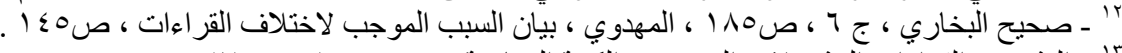

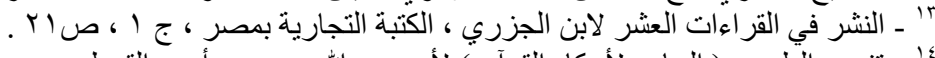

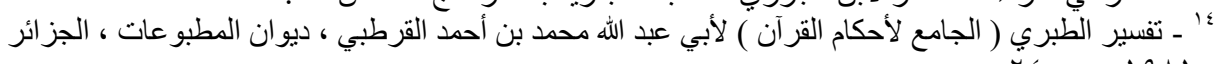




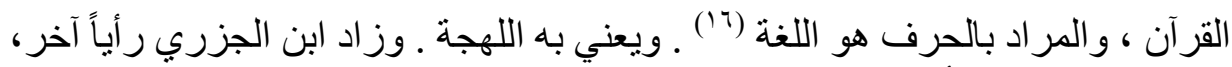

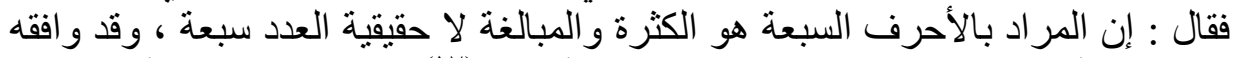

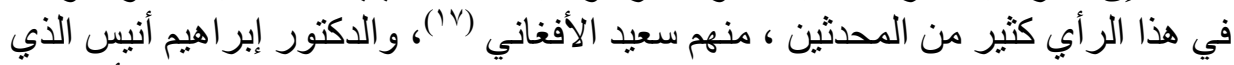

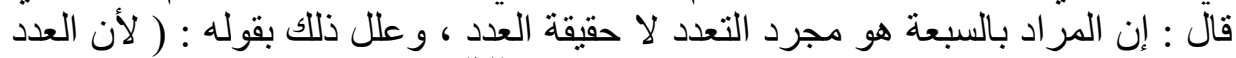

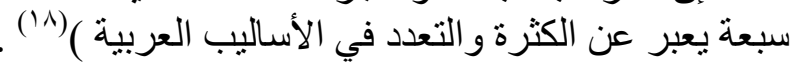

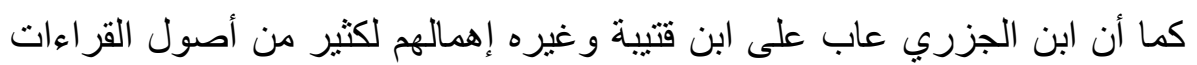

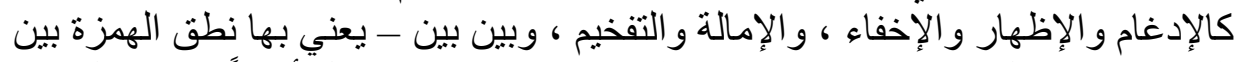

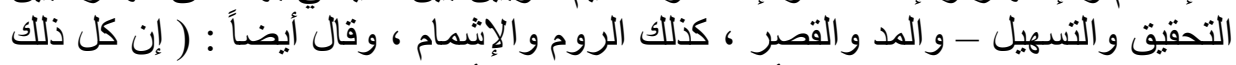

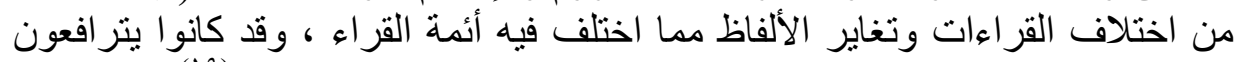

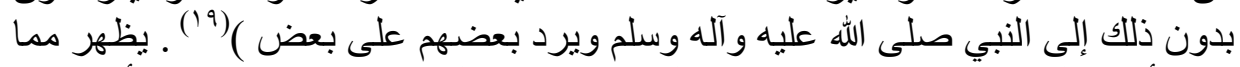

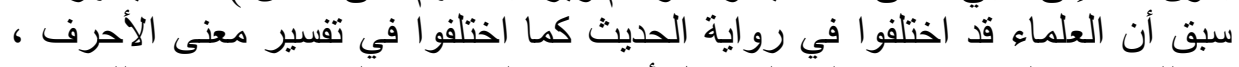

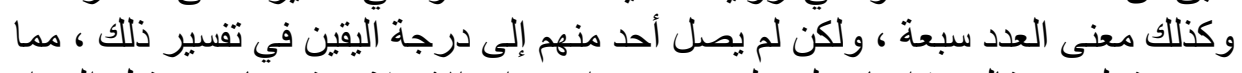

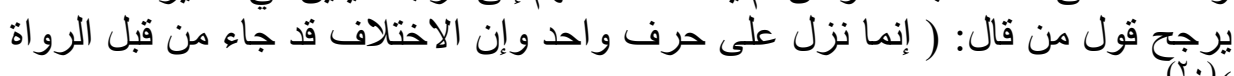

\section{مقاييس القراءة الصحيحة}

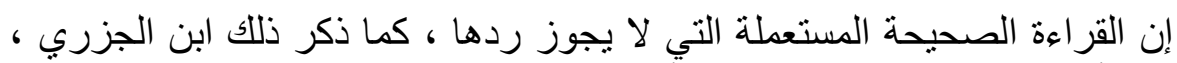

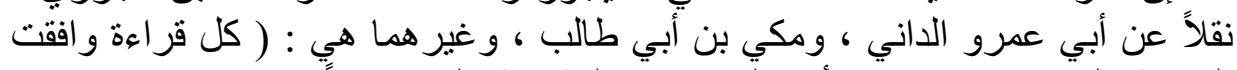

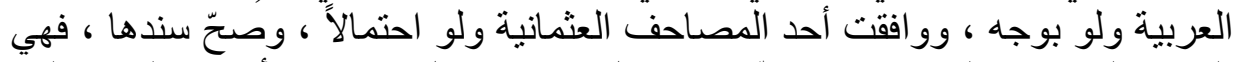

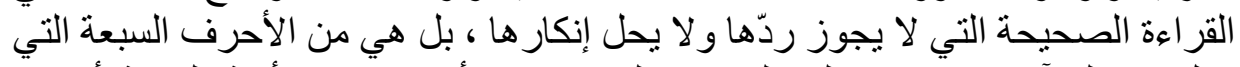

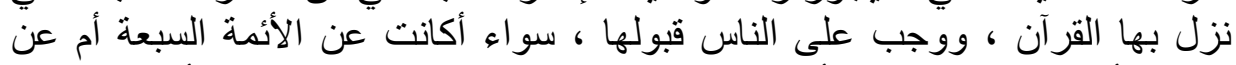

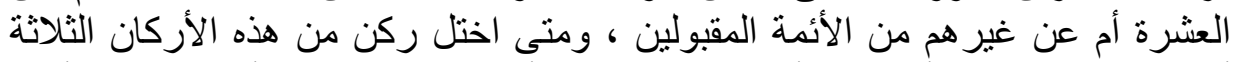

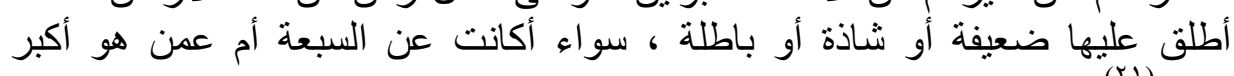

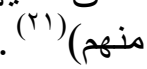
يفهم من النص السابق أن هناك ثلاثة مقاييس يجب أن تتو افر في القراءة بحسب قول من

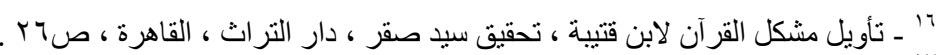

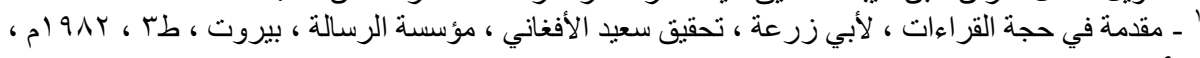

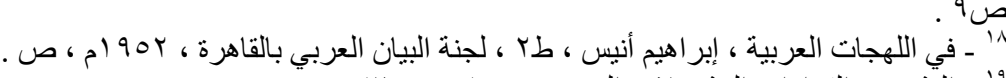

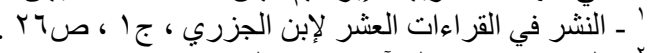

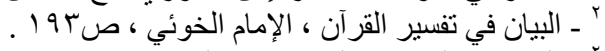

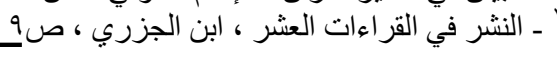




$$
\begin{aligned}
& \text { يرى هذا الر أى لتكون القراعة صحيحة وهي : }
\end{aligned}
$$

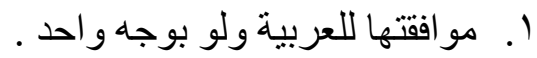

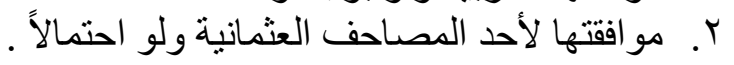

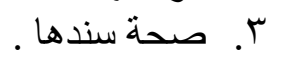

وفيما يأتي توضيح لكل مقياس من هذه المقاييس الثلاثة :

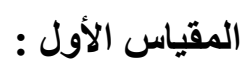

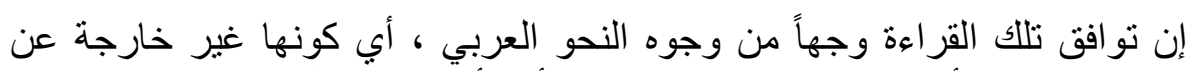

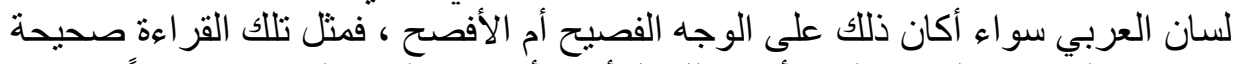

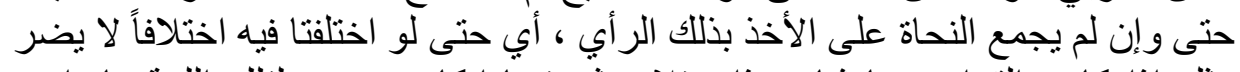

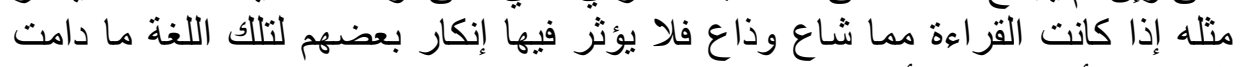

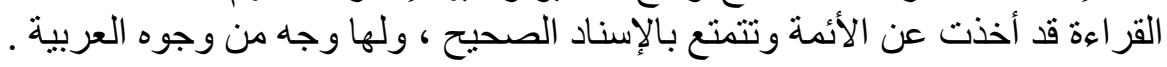

$$
\text { المقياس الثاني : الثرة }
$$

مو افقة القر اعة لأحد المصاحف العثمانية

ويعني به أن تكون تللك القر اءة مو افقة لما رسم في أحد المصاحف العثمانية . لذا لا يصح الأخذ مما خالف رسم المصحف العثماني المجمع عليه .

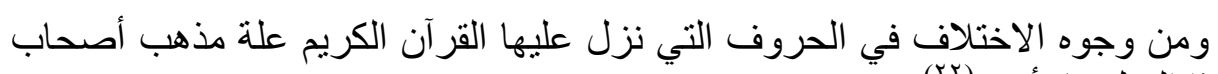

هذا القول ما يأتي: (r)

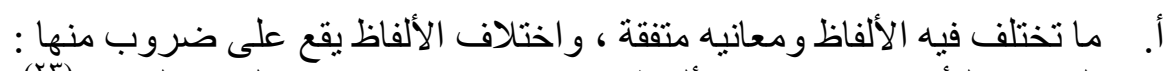

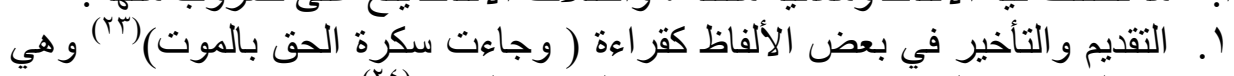

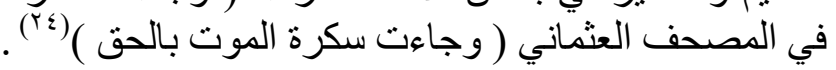

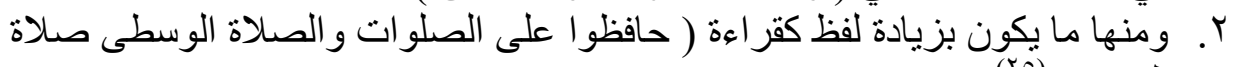
.

$$
\begin{aligned}
& \text { rrr - بيان السبب الموجب لاختلاف القراءات لأبي العباس أحمد بن عمار المهدوي ، تحقيق حاتم الضامن ، ج) ، } \\
& \text { ص ص } 1 \text {. . }
\end{aligned}
$$

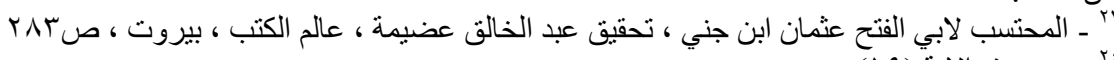

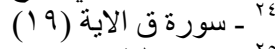

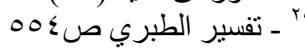


وماورد في المصحف العثماني هو ( حافظو اعلى الصلو ات و الصلوة الوسطي )(بr().

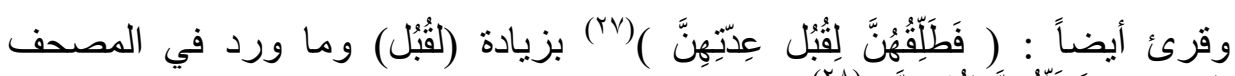

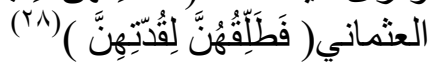

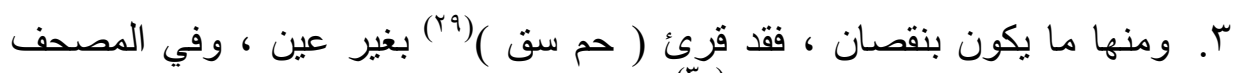

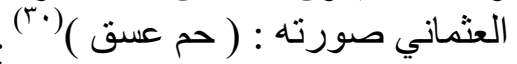

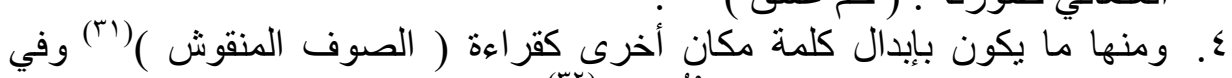

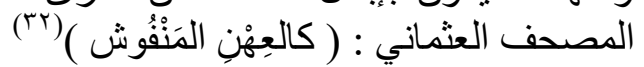

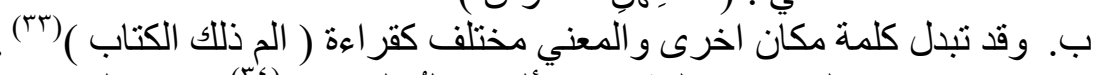

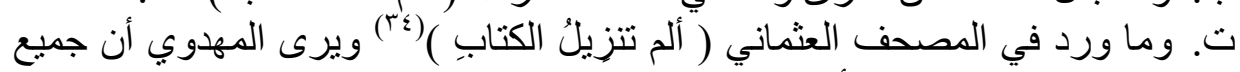

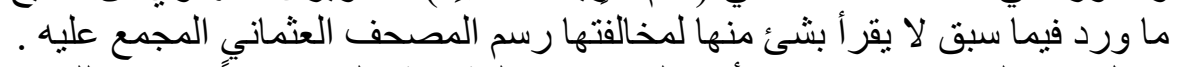

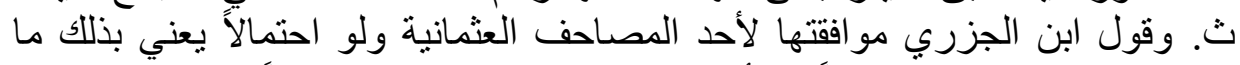

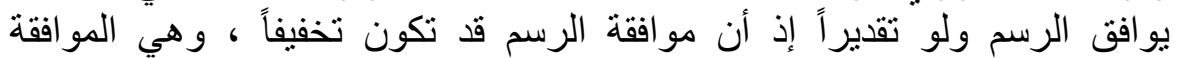

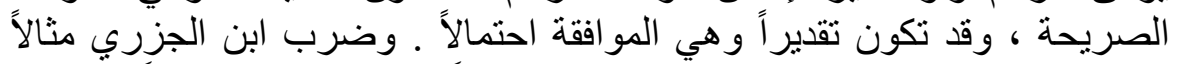

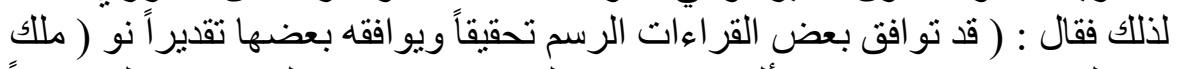

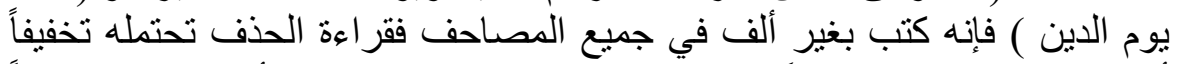

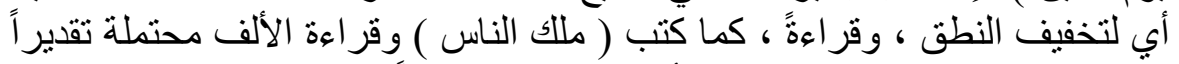

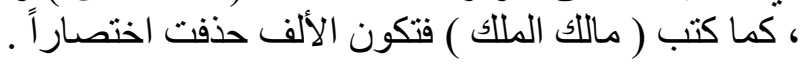

المقياس الثالث : ماتث صحة السند :

فسّر ابن الجزري عبارة ( صحة سندها ) بقوله : ( نعني به أن بروي تلكي الك القر اءة

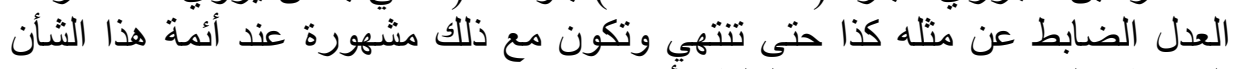

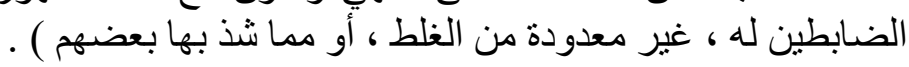

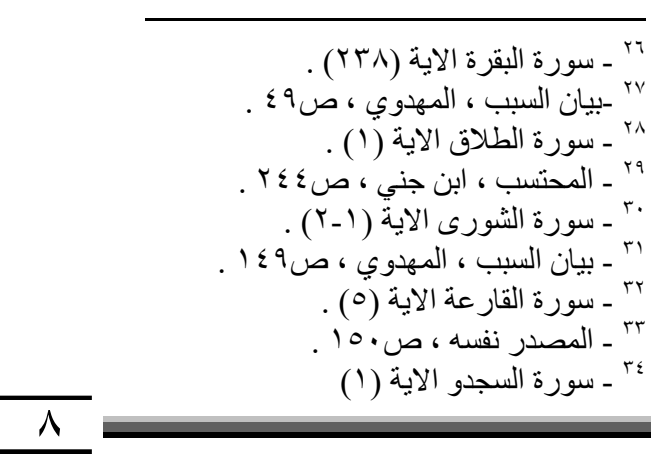


نستتج من النص السابق أن القراعة الصحيحة يجب أن يتو افر ركن آخر ، هو أن يكون سند تللك القر اعة صحيحاً.

\section{وتتحقق صحة السند بما يأتي :}

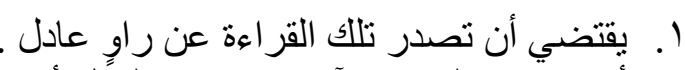

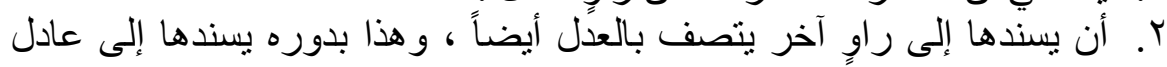

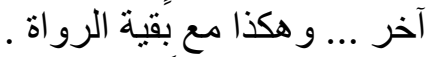
r. تسند الرو اية أخيرًاً إلى الصحابي الرواة الذي سمعها من النبي صلى الله عليه وسلم . كما ذكر ابن الجزري شروطاً أخرى تثبت صحة القراءة هي :

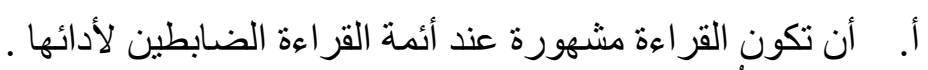

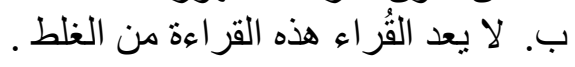

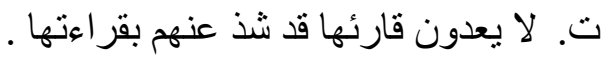

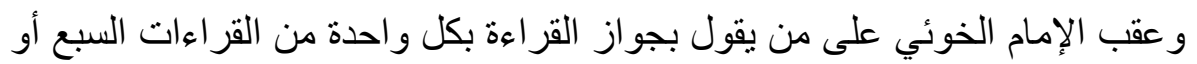

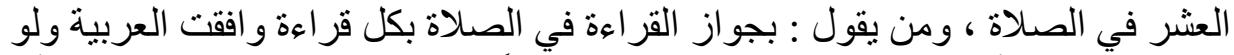

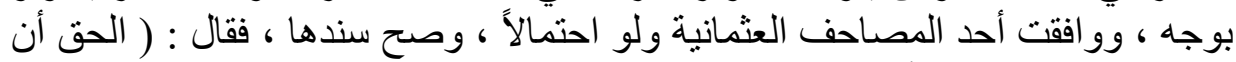

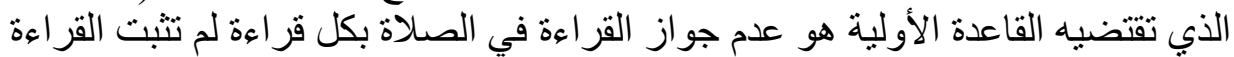

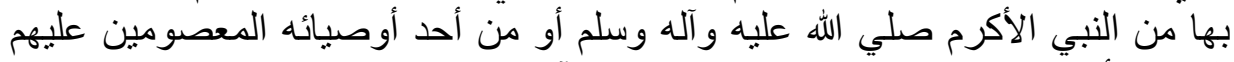

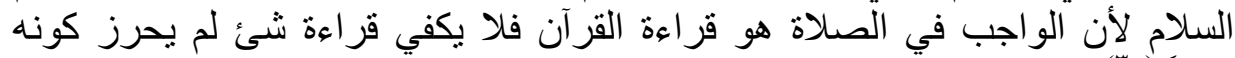
قر آناً) (ro)

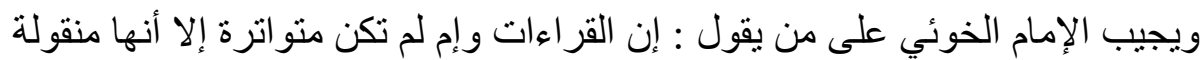

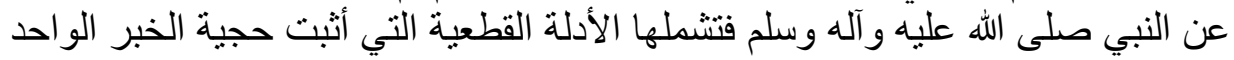

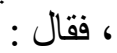
( أولاً : إن القراءات لم يتضح من كونها رواية لتشملها هذه الأدلة ، فلعلها اجتهادات من القراء )

( ثانياً : إن رواة كل قراءة من هذه القراءات لم يثبت وثاقتهم أجمع ، فلا تشمل أدلة

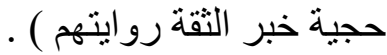

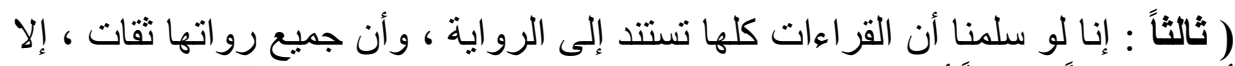

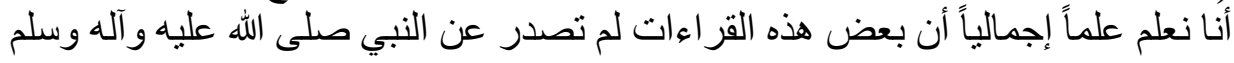




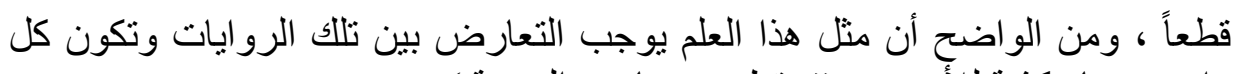

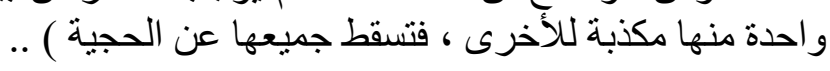

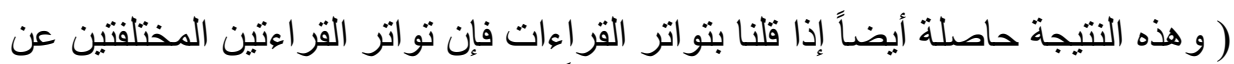

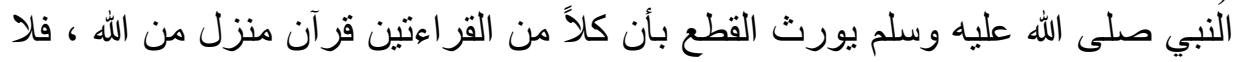

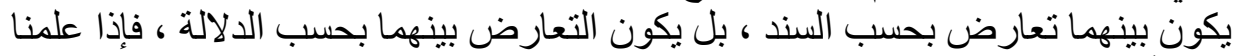

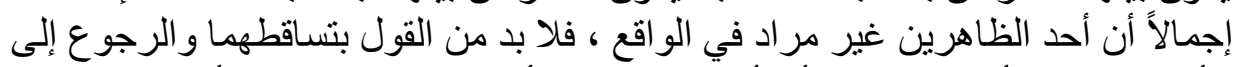

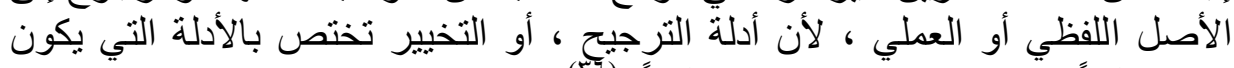

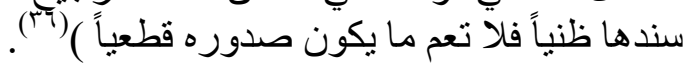

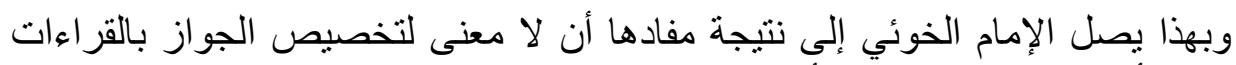

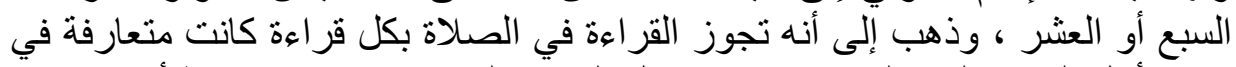

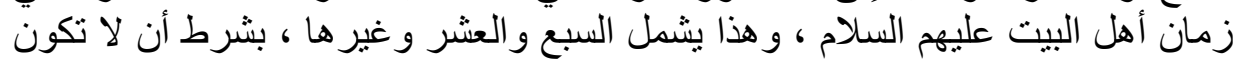

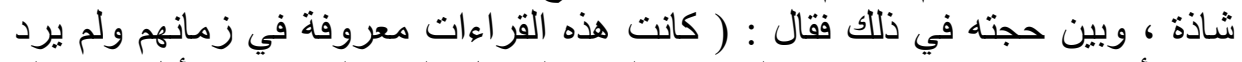

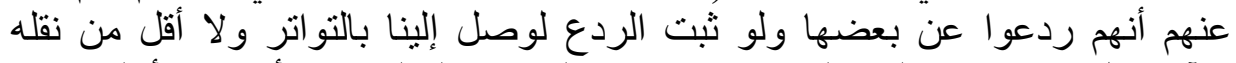

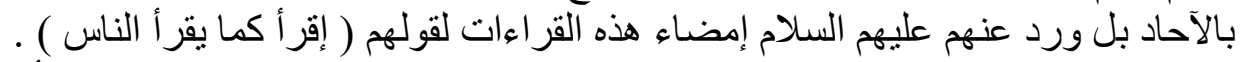

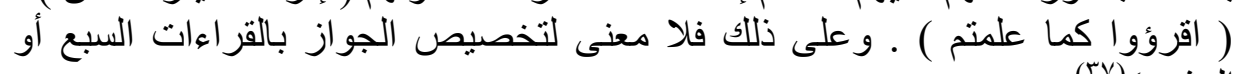
(العشر (أرؤ (rv)

\section{المبحث الثاني}

$$
\text { أنواع القزاعة التعانية }
$$

أنواع القراعات

تتحدد أنواع القراءات بحسب رأي من ذكر المقاييس الثناثة السابقة الذكر على النحو الآتي :

1/ القراعة المتواترة : المي

و هي القراءة الصحيحة المنسوبة للقُراء السبعة أو لغيرهم ، وهي التي تتوافوة فئرة فيها المقاييس الثلاثة السابقة المانة

r/ القراعة الثناذة : ذهب القُر اء في تعريف هذه القراءة مذهبين : 
الفريق الأول : يسمى القراعة شاذة عند نو افر المقياس الأول ( وهو موافقتها العربية )

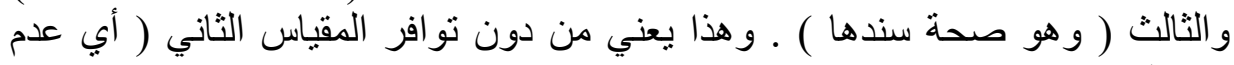

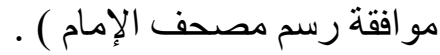
وتسمى هذه القراءة شاذة ، لكونها شذّت عن رسم المصحف المجمع عليه ، وإن كان سند ها صحيحاً.

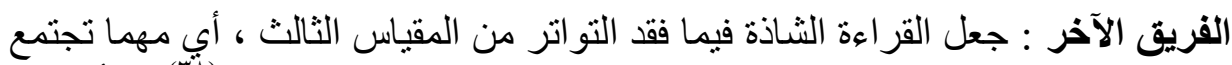

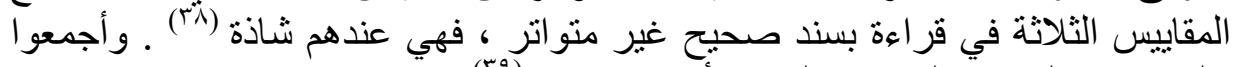

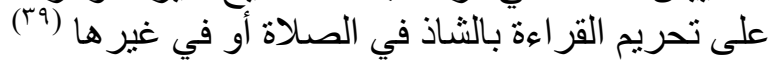

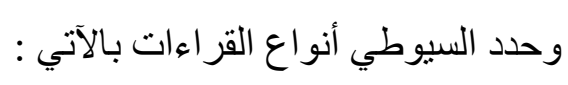

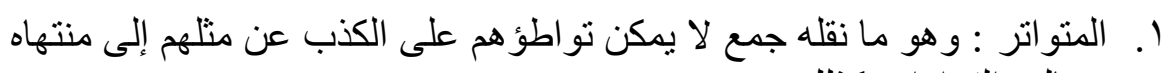

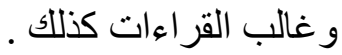

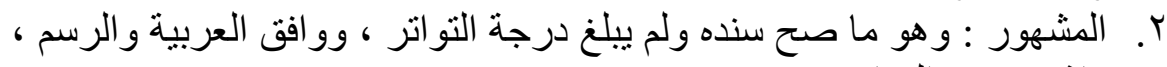
واشتهر عن القراء. r. الآحاد : وهو ما صح سنداء الثر وخالف الرسم أو العربية أو لم يشتهر بالاشتهار

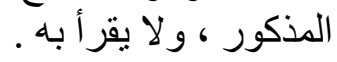

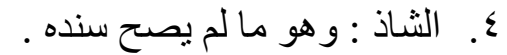

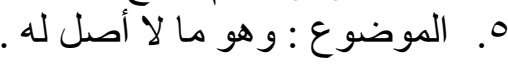

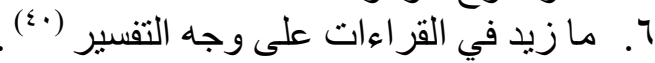

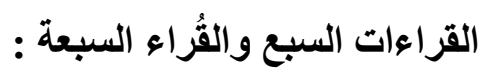

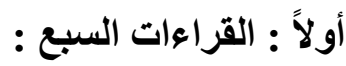

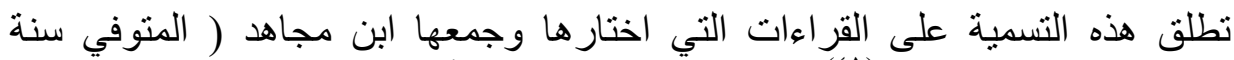

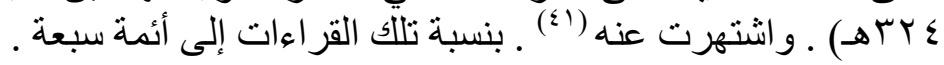

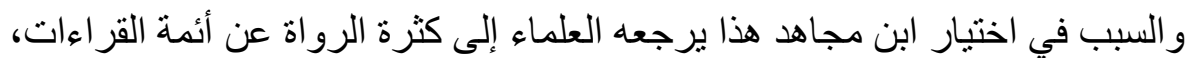

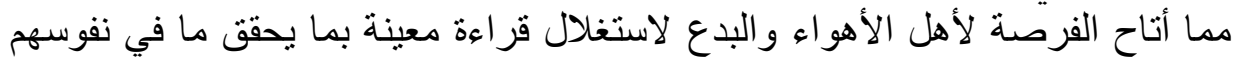

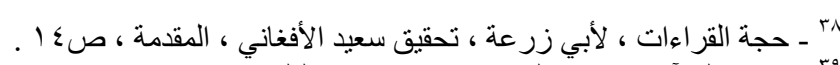

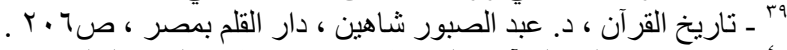

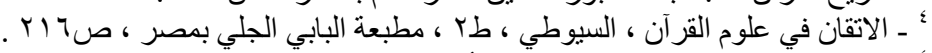

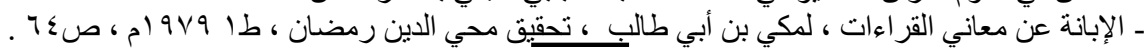


من أغر اض ، لذلك تحفز العلماء للاعتناء بشأن القرآن الكريم وحصر قر اءاته على أئمة

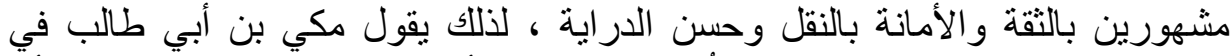

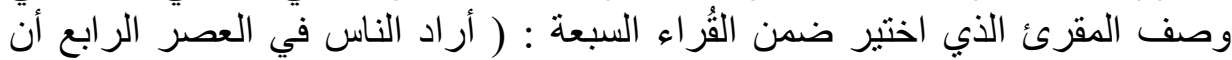

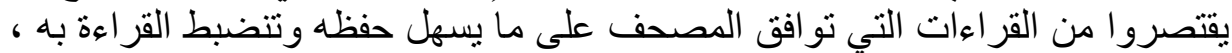

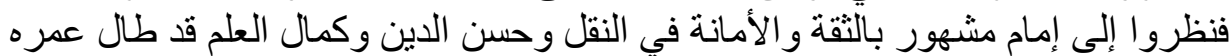

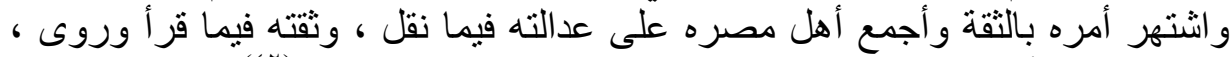

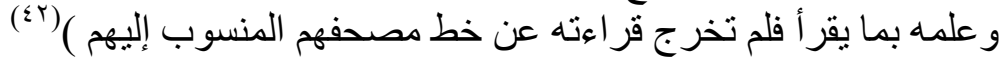

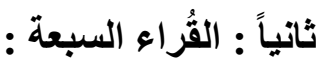

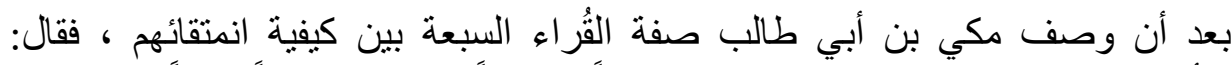

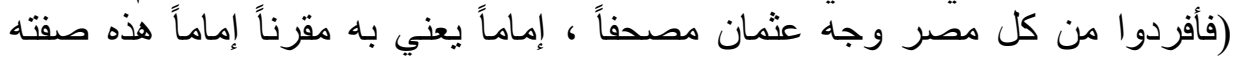

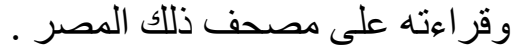

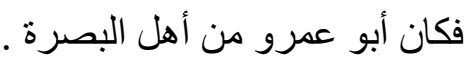
وحمزة وعاصم من أهل الكوفة وسوداها ، و الكسائي من أهل الكوفة أيضاً ، وهو مولى الئ بني أسد ، من تابع التابعين . ماهن

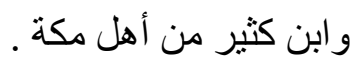

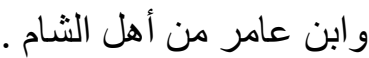

ونافع من أهل المدينة ، كلهم ممن اشتهرت إمامته ، وطال عمره في افراء واء وارتحال

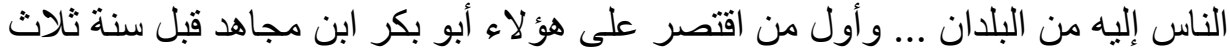

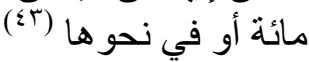

\section{المصحف العثماني والمصحف الإمام :}

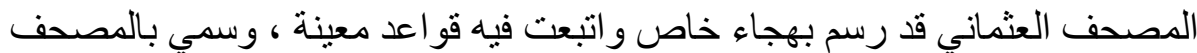

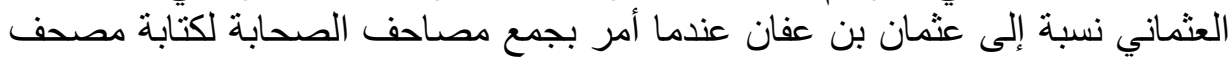

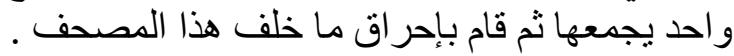

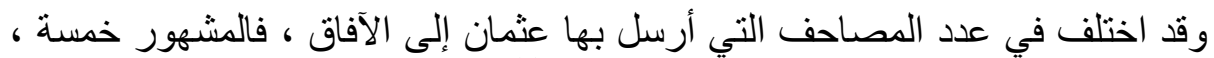

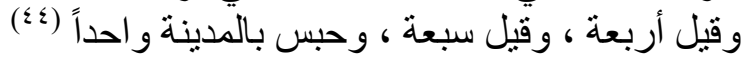

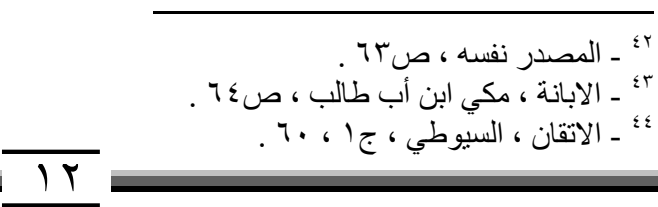




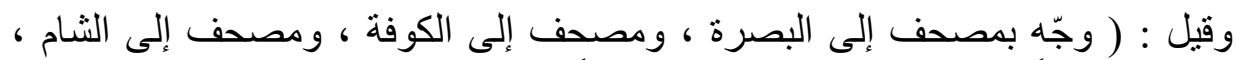

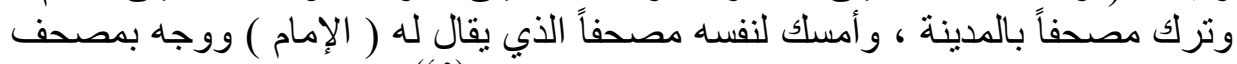

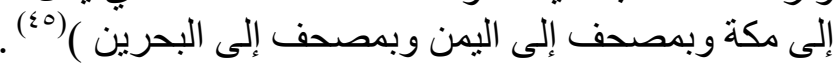

هل المصحف العثماني مشتمل على الأحرف السبعة ؟

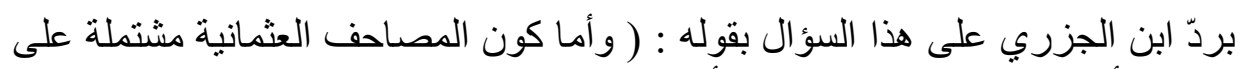

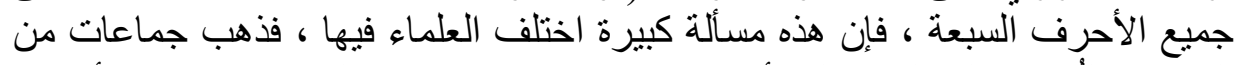

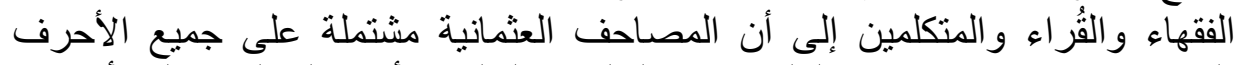

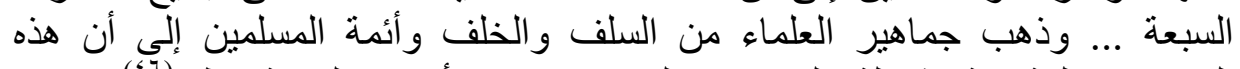

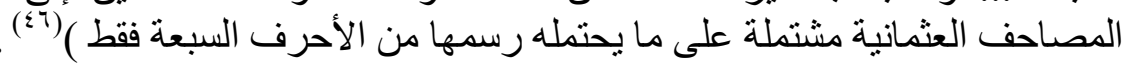

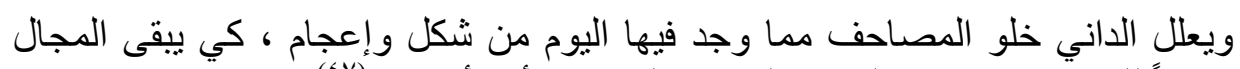

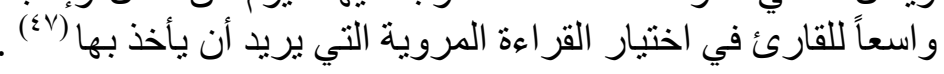

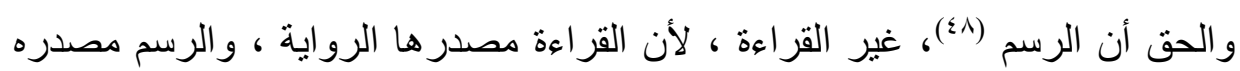

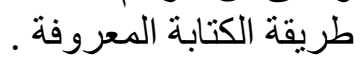
وذكر ابن قتيبة في تأويل مشكل القرآن أن الرسم العثماني اختلف عن الرسم الإملائي

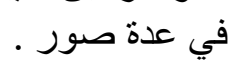

فألف الاثثين تحدف في هجاء هذا المصحف في كل مكان مكان مثل ( قال رجلن ) فالألف

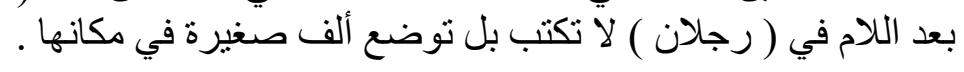

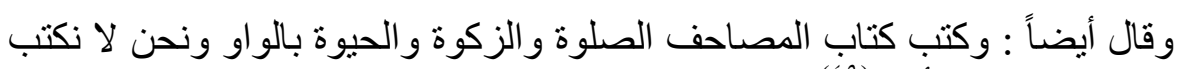

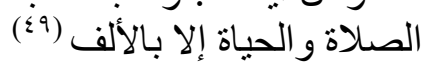
وسيتضح لنا سبب كتابة الألف واواً في أداء بعض القراء الاءات القرآنية عند الحديث عن

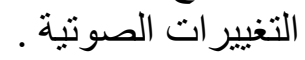

\section{المبحث الثالث}

الظواهر الصوتية في القراءات القرآنية

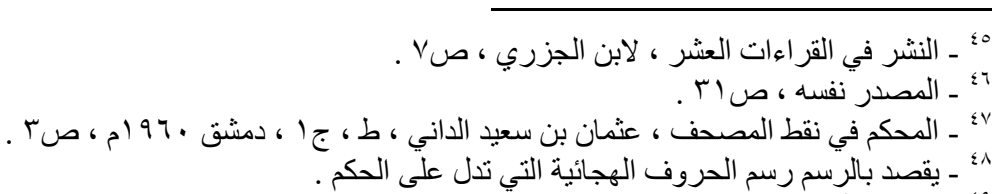

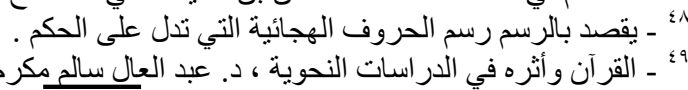

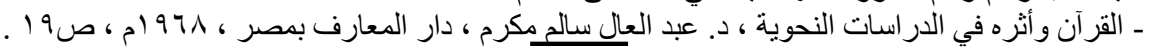


وهي التغيرات الصوتية في أداء بعض القراءات القر آنية .

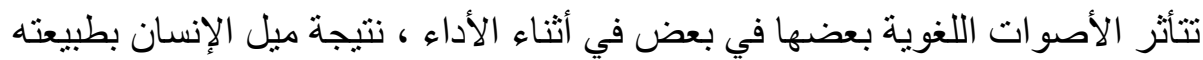

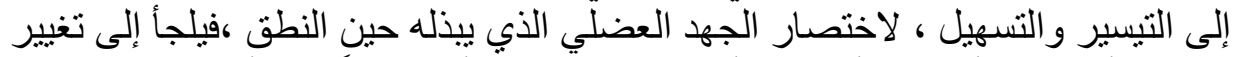

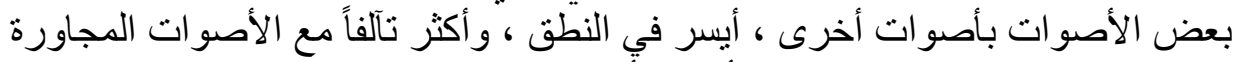

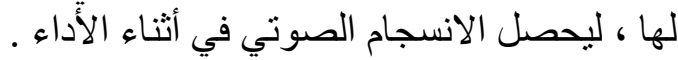

ومن تللك المظاهر الصوتية التي وردت في أداء بعض القر اءات القر آنية ما يأتي :

أولاً : تسهيل الهمزة وتخفيفها :

تسهيل الهمزة معروف منذ القدم ، حيث مالت كل اللهجات السامية إلى التخلص منه

في النطق (o.)

أما عند العرب فكان تحقيق الهمزة من خصائص لهجات القبائل البدوية ، وهي التي

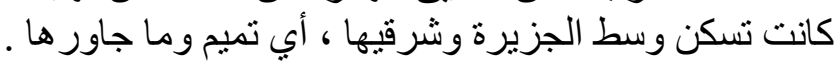

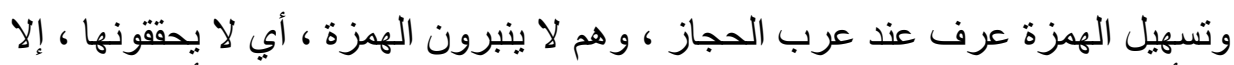

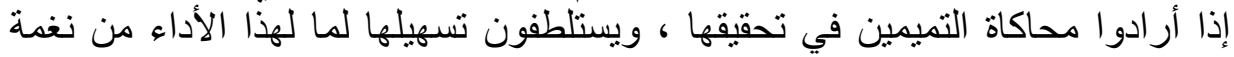

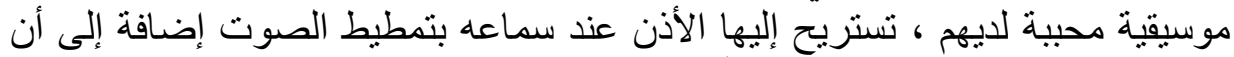

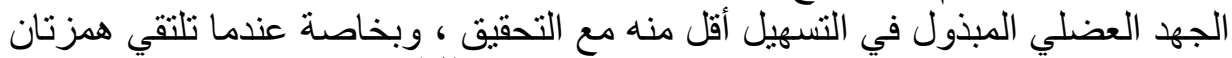

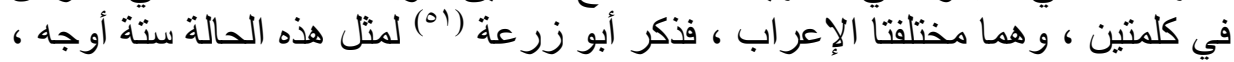

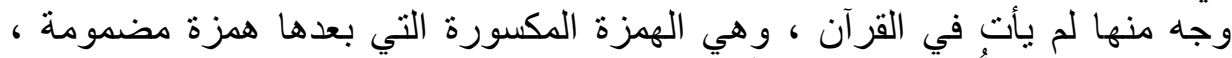

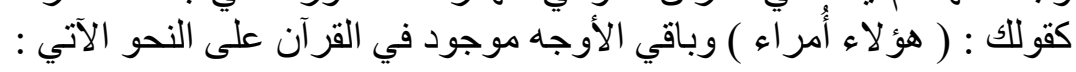

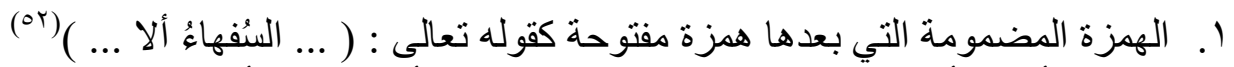

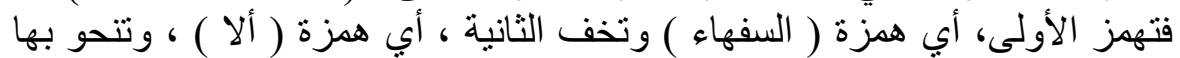

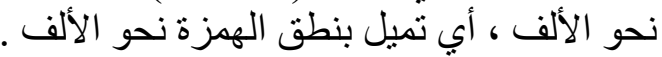

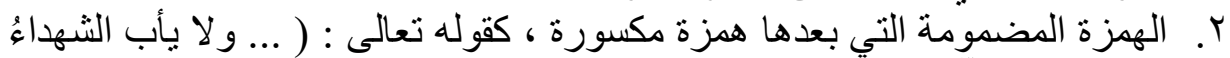

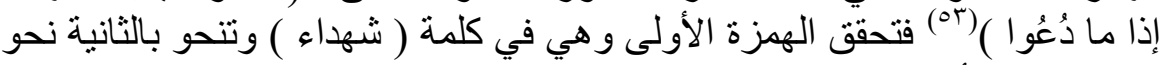

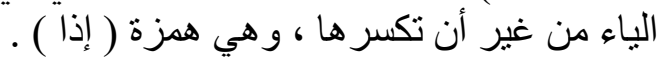

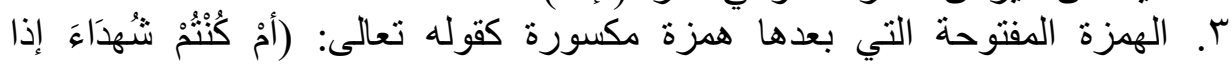

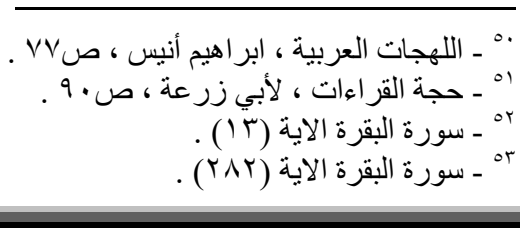


حضر ...) (؛) ـ فتحقق الهزة الأولى ، وهي همزة ( شهداء ) وتتحو بالثانية نحو

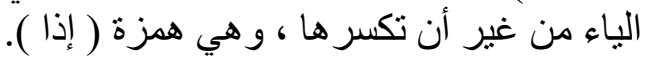

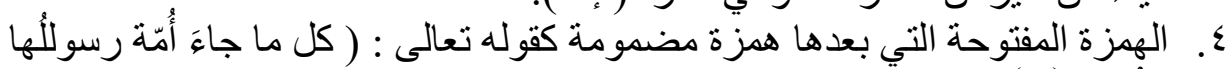

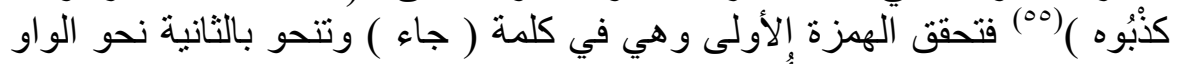

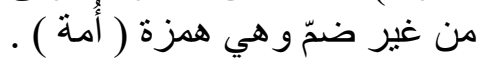

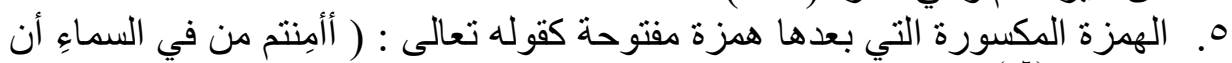

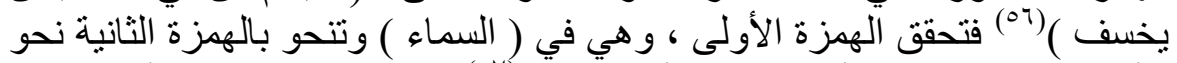

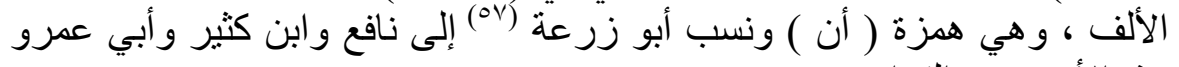

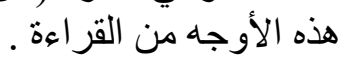

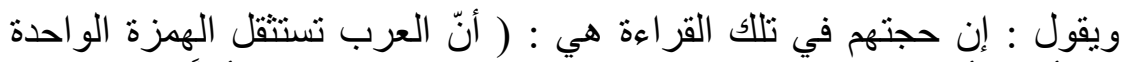

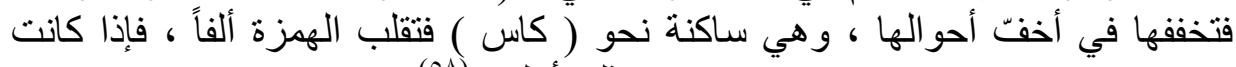

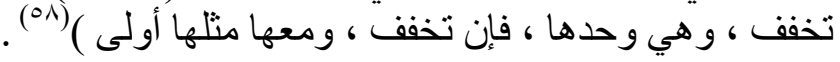

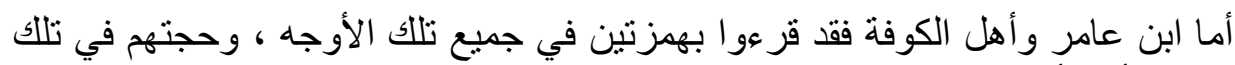

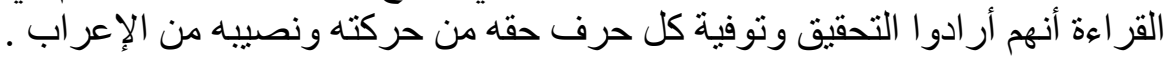

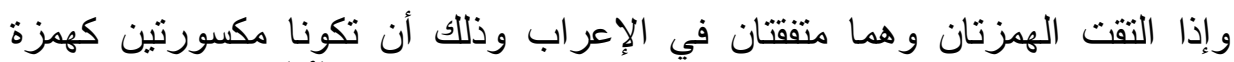

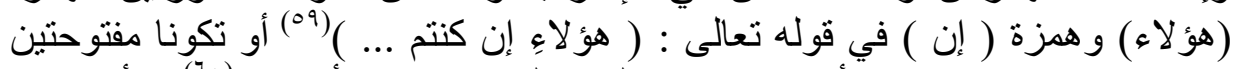

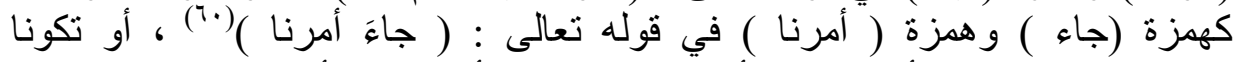

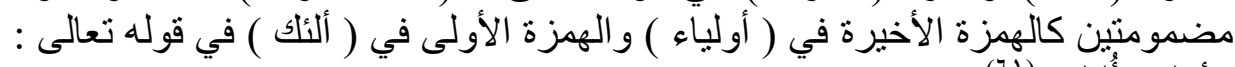

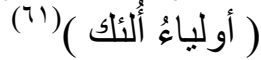

فقر أ ابن عامر و أهل الكوفة جميع ذلك بتحقيق الهمزتين . وقراءة ورش عن نافع ، والقواس عن ابن كثثر بتحقيق الهمزة الأولى ويلينان الثانية

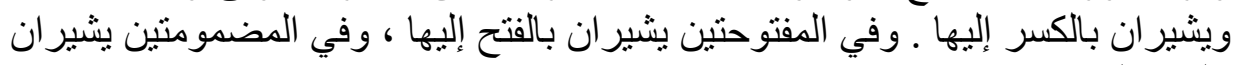
بالضم إليها .

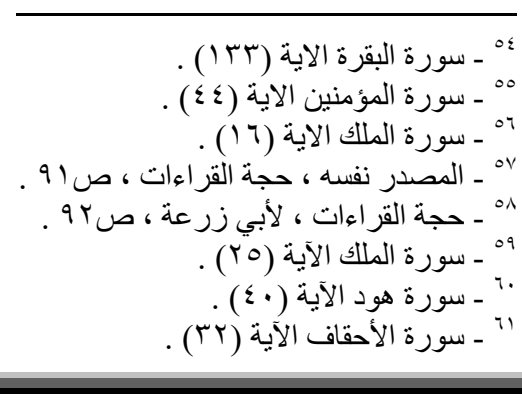




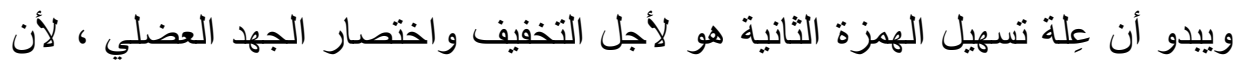

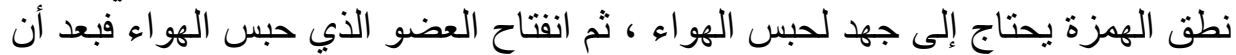

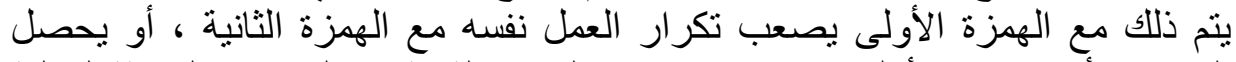

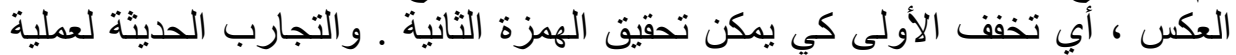

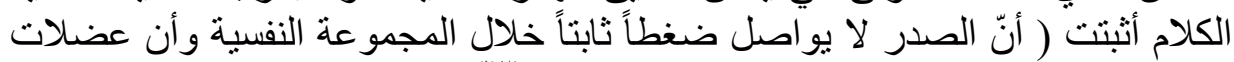

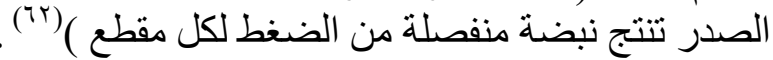

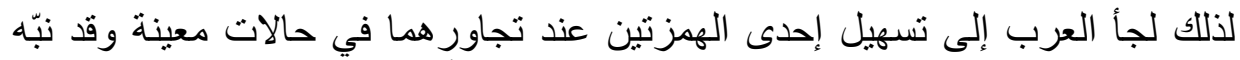

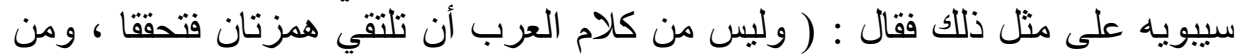

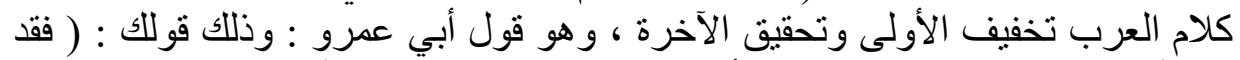

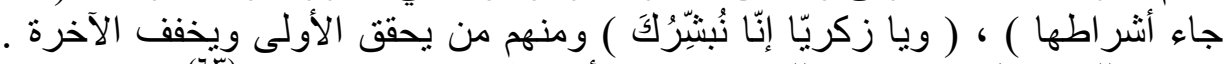

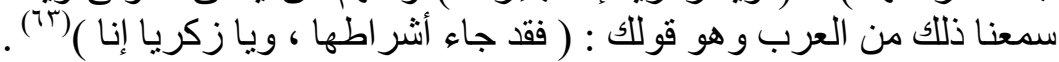

ومن أمثلة القراعات التي ورد فيها تسهيل إحدى الهمزتين المتجاورتين :

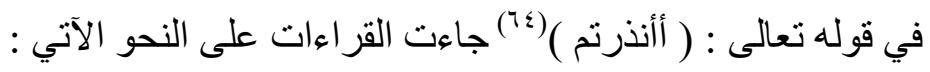

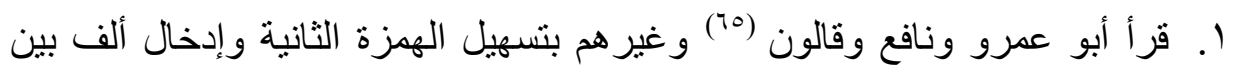

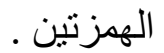

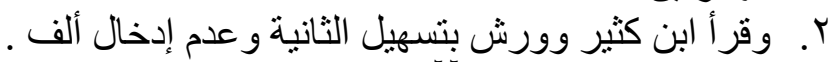

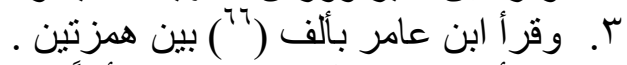
ع. وقر أ ورش بإبدال الهززة الثنانية ألفاً.

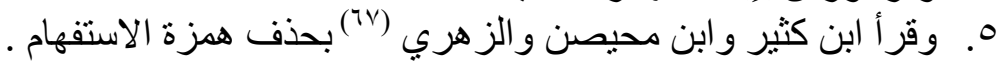

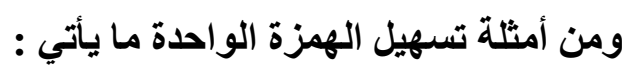

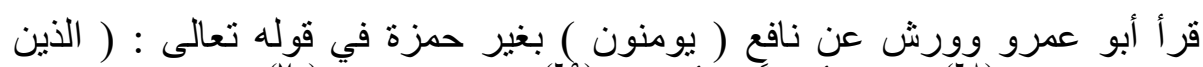

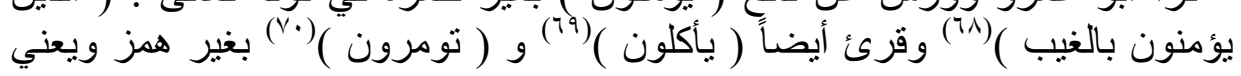

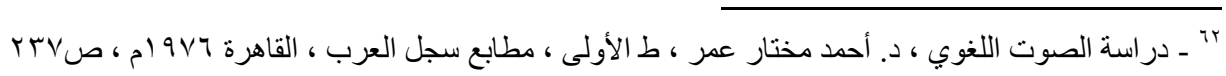

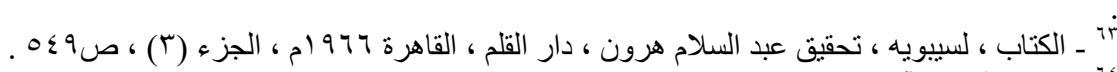

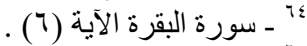

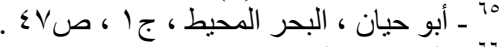

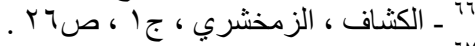

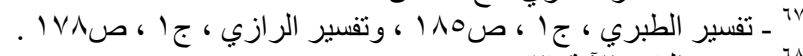

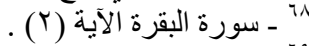
ـ" سورة البقرة الآية (YVO (Y) ). 


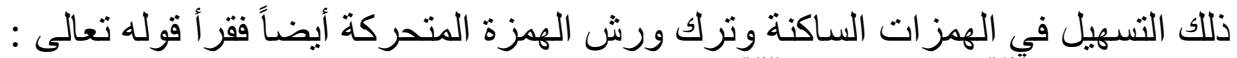

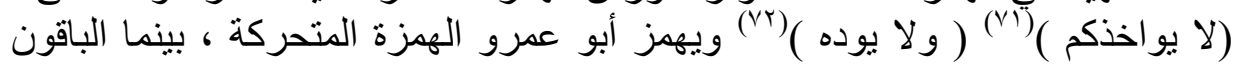

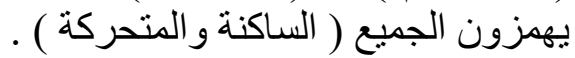
ثنانياً : اختلاس الحركة :

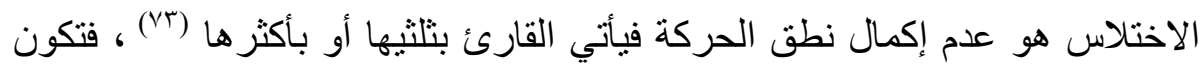

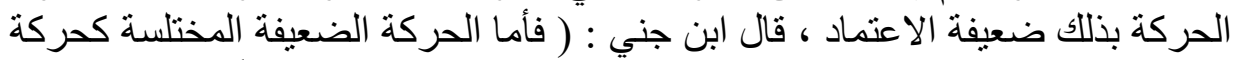

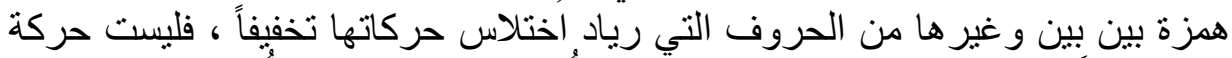

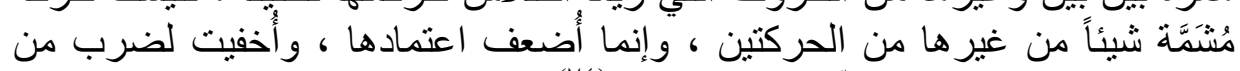

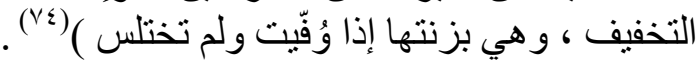

\section{ومن أمثلة القراءات التي وردت باختلاس الحركة ما يأتي :}

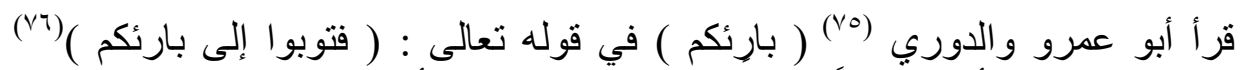

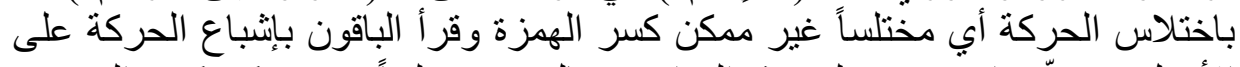

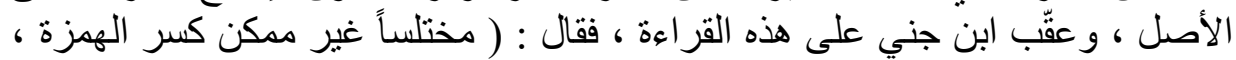

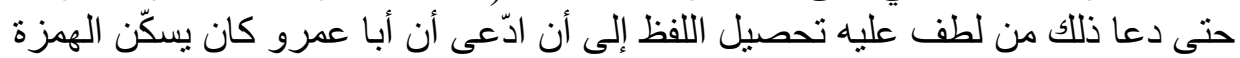

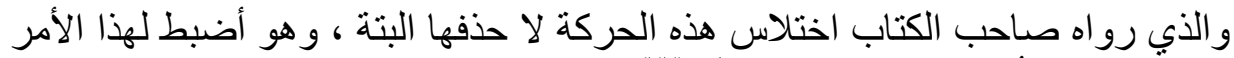

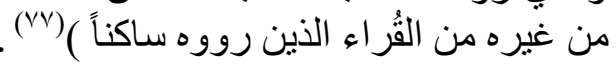

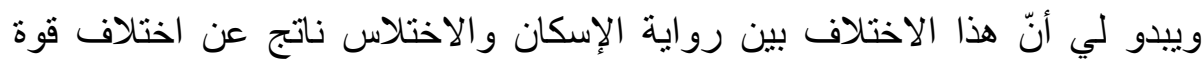
السمع بين الرواة ، فمن تتصف أذنه بقوة السمع يحس باختلاس الحركة و العكس صحيح.

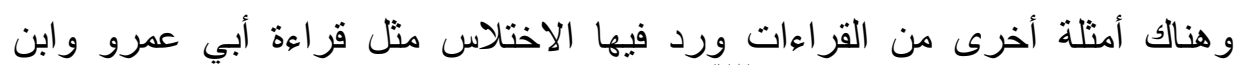

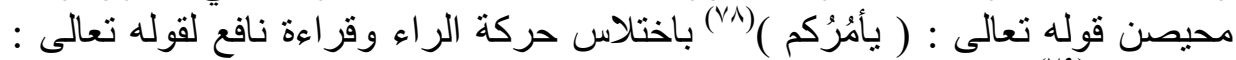

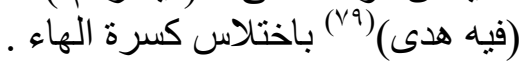

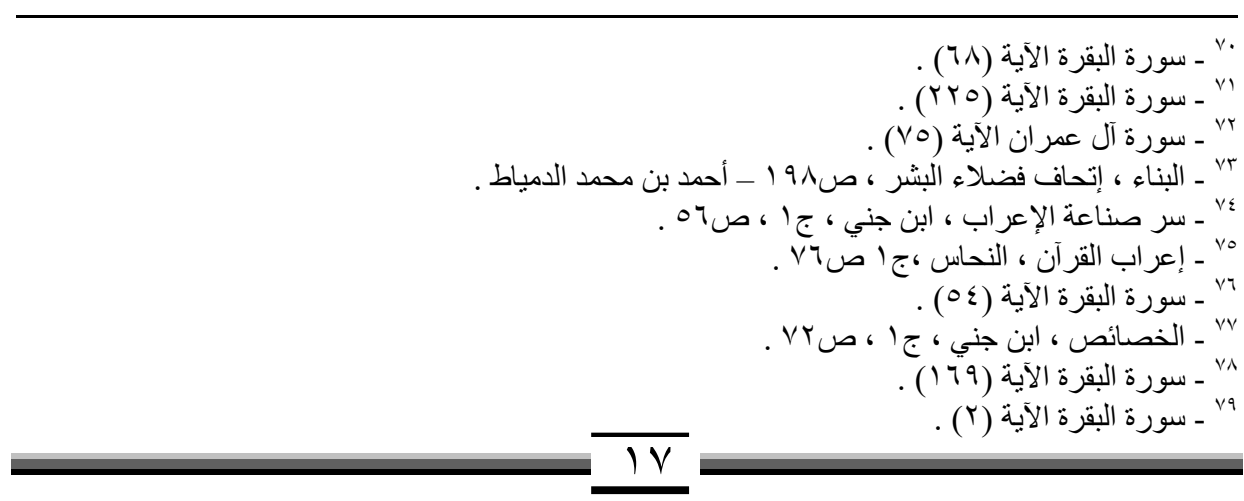


قلنا : إن الأصوات اللغوية يتأثر بعضها في بعض في أثناء الأداء تأثراً ائودي أحياناً إلى ألى

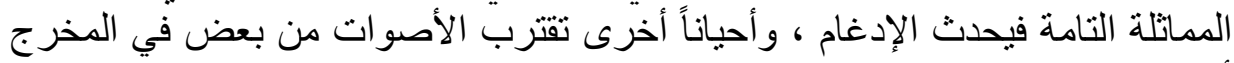
أو الصفة ، فتحدث المماثلة الجزئية .

وتختلف الأصوات في نسبة التأثر ، فهناك من الأصوات ما ماتيكون سريع التأثر

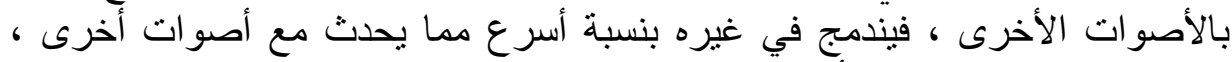

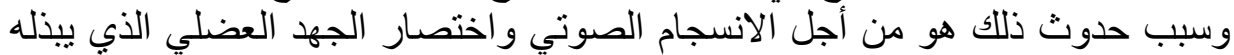

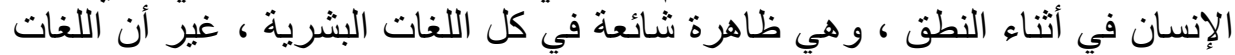

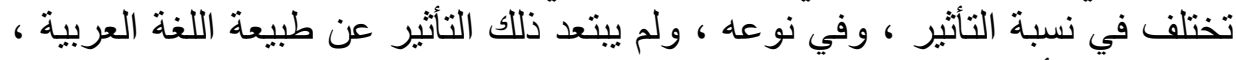
وبخاصة في أثناء تطور ها في لهجات في نو الكلام .

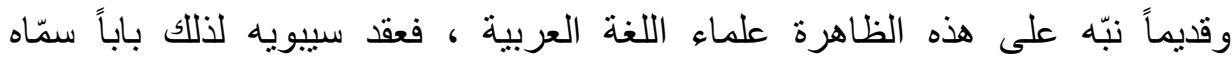

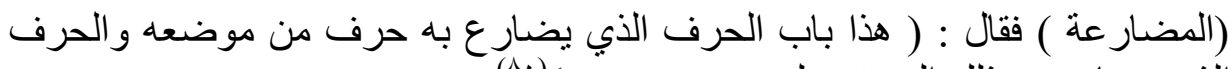

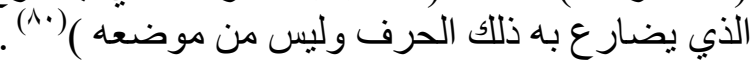

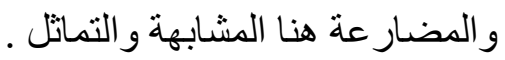

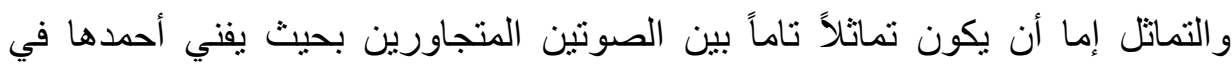

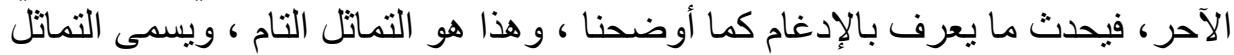
الكلي. و أما أن يكون التماثل غير تام فيحدث التقارب وهو ما يسمى بالتماثل الجزئي . وفيما يأتي تفصيل ذلك :

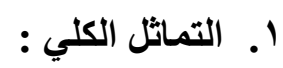
من التماتل الكلي الذي بسمع في الأداء القر آني والإدغام .

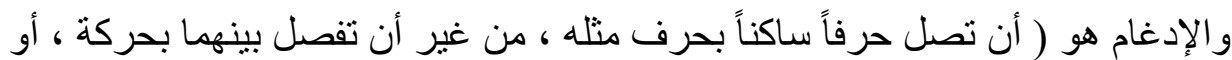

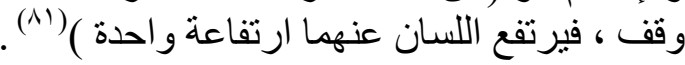
ويأتي الإدغام على ضربين : أ. . إدغام المثلين : ويحدث هذا الإدغام بين الصوتين المتماتلين سواء أكان الأول منهما

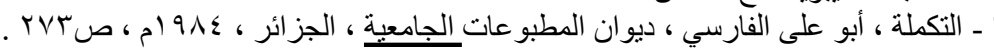


ساكناً في الأصل كالطاء من ( قطّع ) و أصلها قططَع أم متحركاً كالميم الأولى من

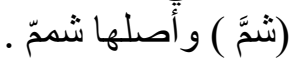

ويحدث الإدغام عند اجتماع حرفين متماثلين في كلمتين متجاورتين ويكون الأول

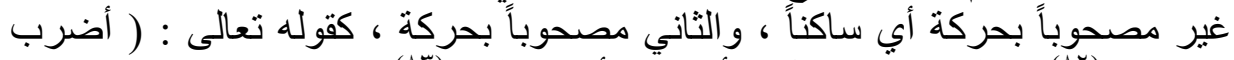

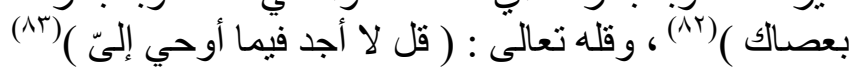
و إذا التقي المثلان المتحركان وجب الإظهار ، ولكن قرأ أبو عمرو ويعقوب ( مناسِكُمْ )

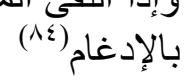

$$
\begin{aligned}
& \text { في قوله تعالى : ( مناسِكَكُم) (10) } \\
& \text { ب. إدغام المتقاربين : }
\end{aligned}
$$

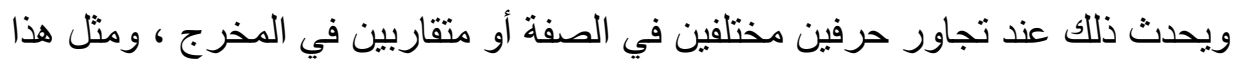

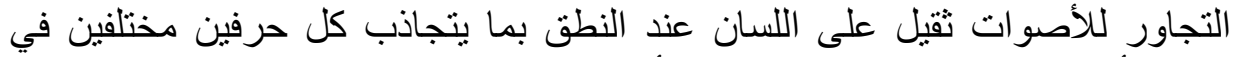

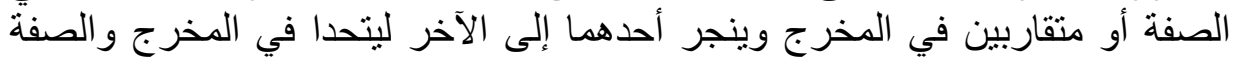

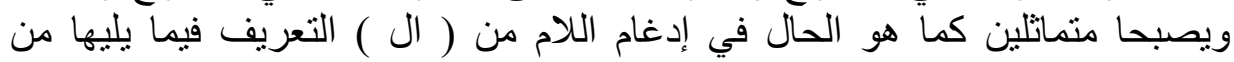

$$
\text { الحروف الثمسية . }
$$

و الحالة الثانية هى إدغام النون الساكنة ، ومثلاها التنوين مع بعض الحروف الأخرى .

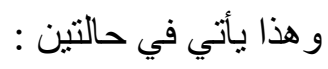

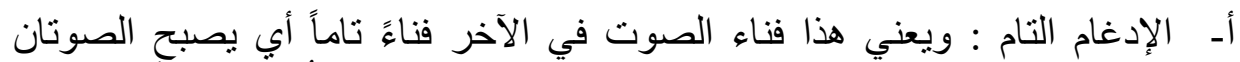

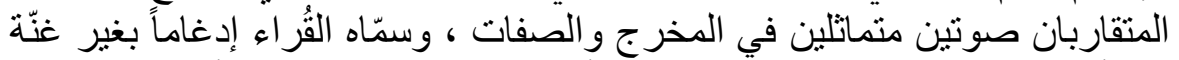

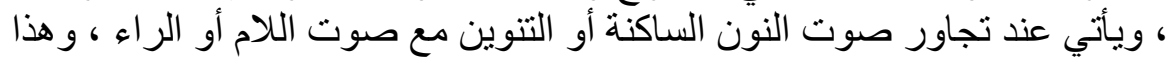
مشهور عند علماء التجويد . منائ.

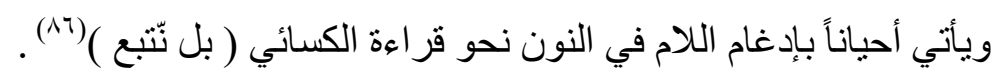

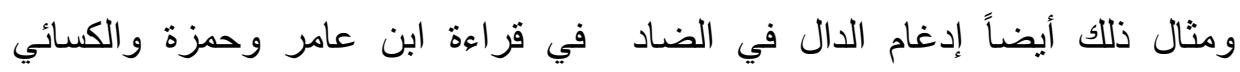

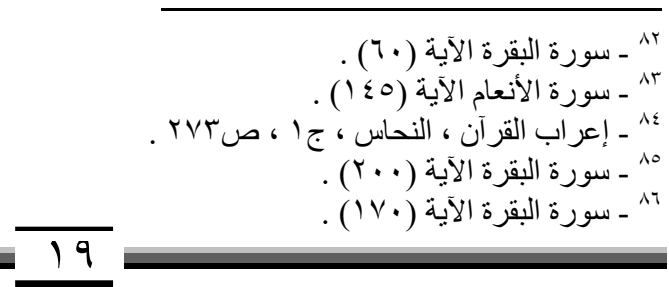




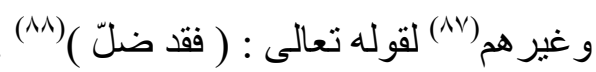

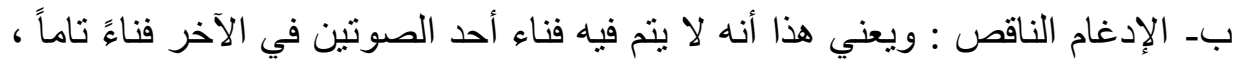

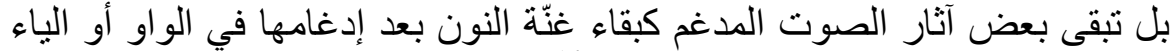

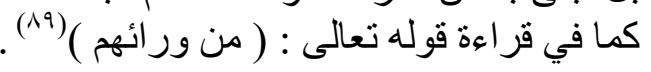

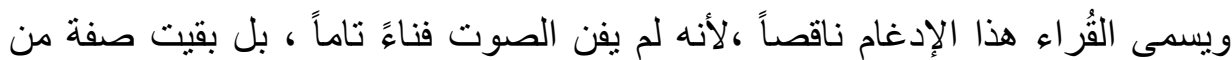

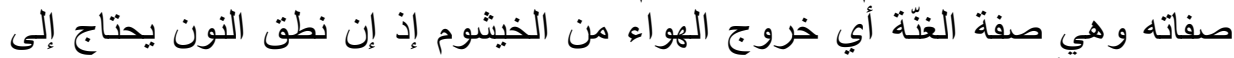

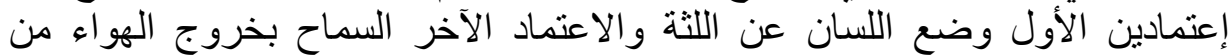

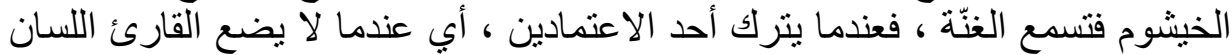

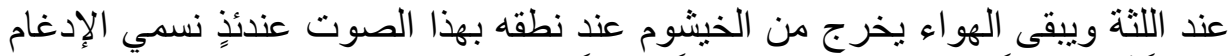

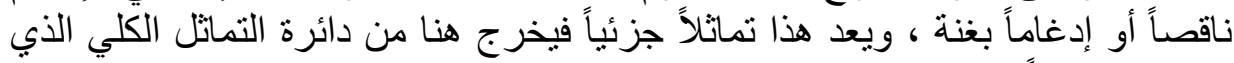
نتكلم عنه حالياً.

وجميع الأصوات تقبل الإدغام في بعضها إلا أصوات الحلق فإنها تستعصي على الإدغام

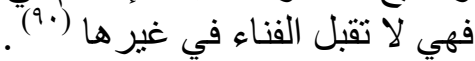

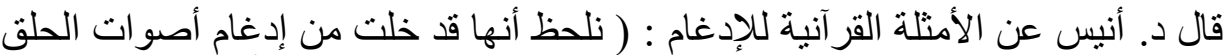

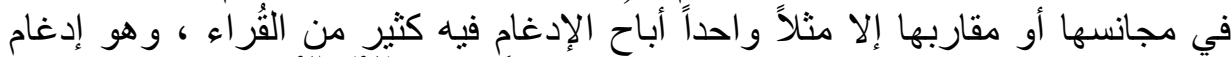

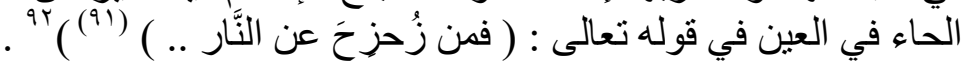

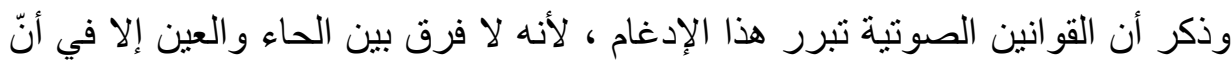

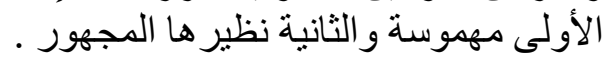

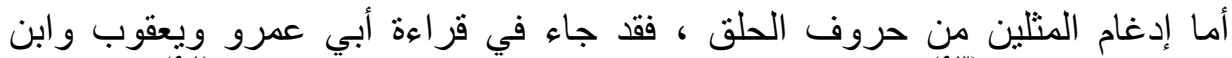

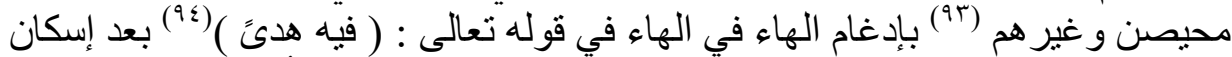

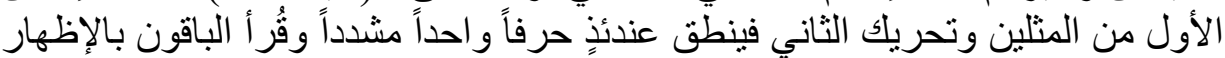

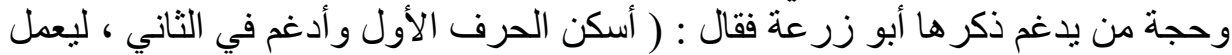

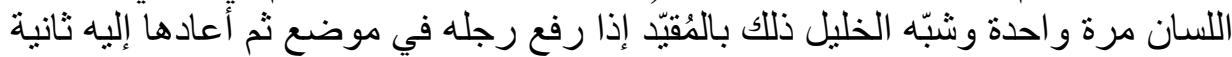

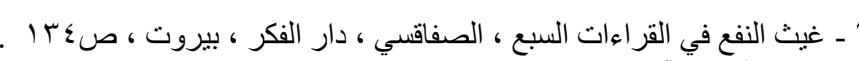

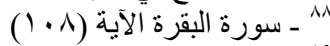

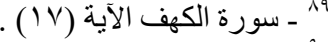

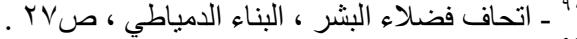

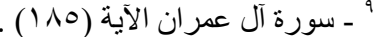

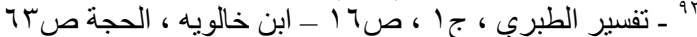

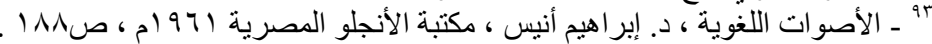


قال : و الذي أوجب الإدغام هو أن ينقل على اللسان رفعه من مكان و إعادنه في ذلك

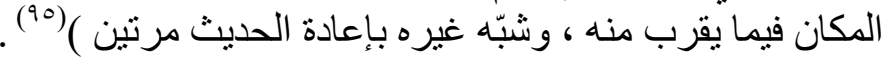

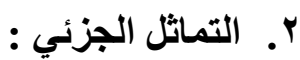

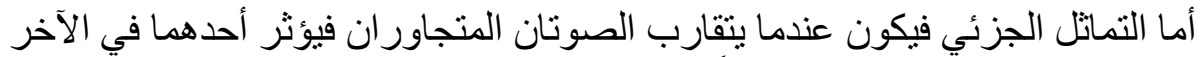

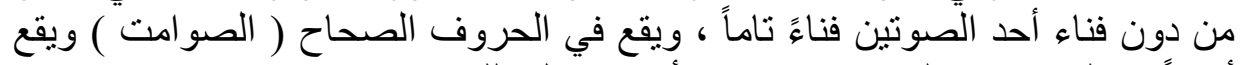

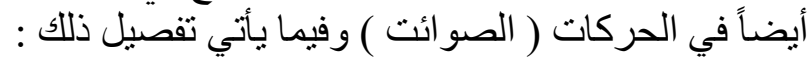

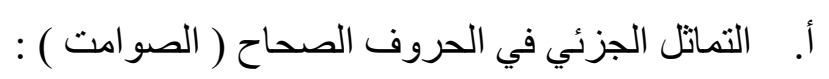

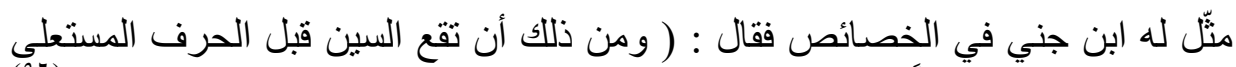

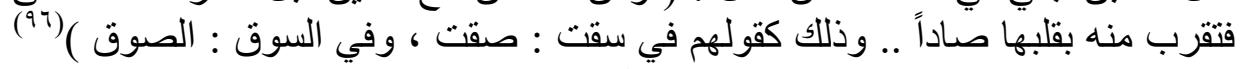

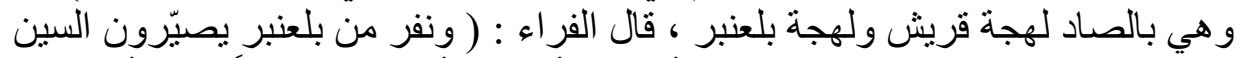

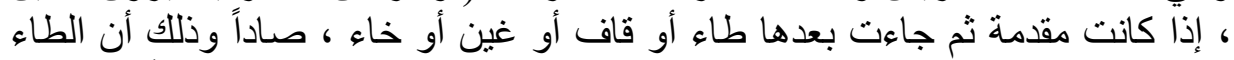

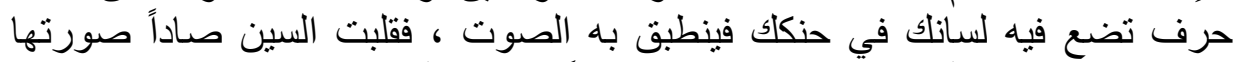

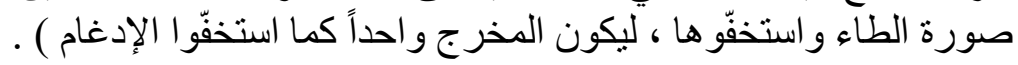

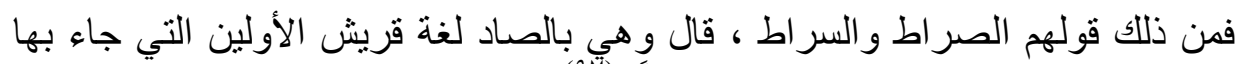

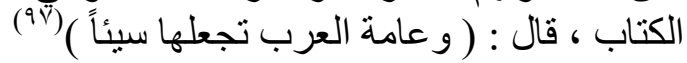

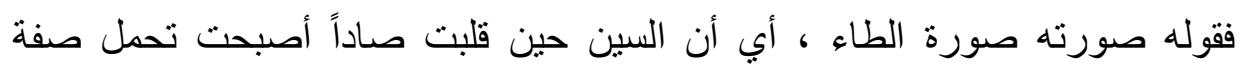

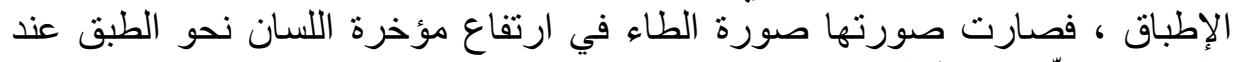

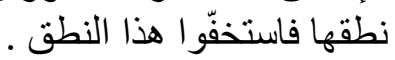

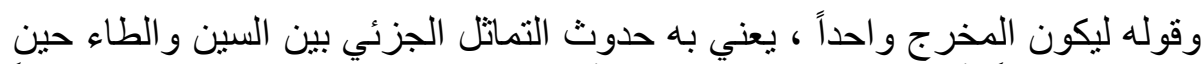

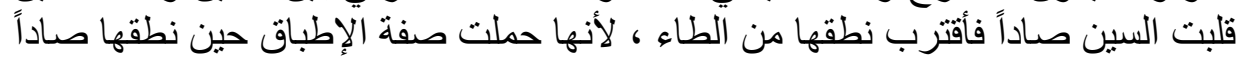

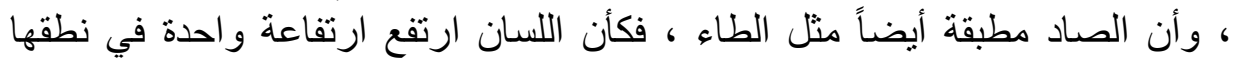

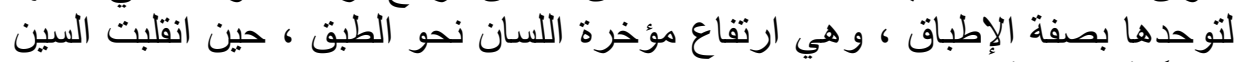

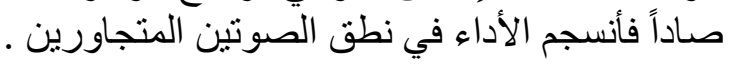

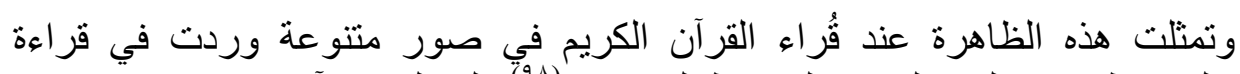

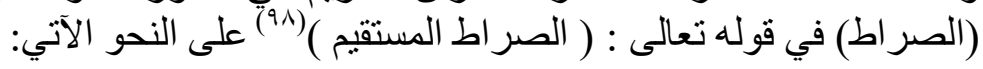

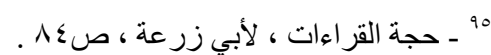

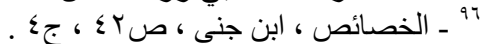

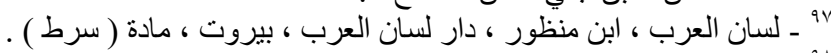


ا ـ قرأ ابن كثير والكسائي وأبو عمرو ويعقوب وغير هم ( السراط ) بالسين على الأصل . أن المن

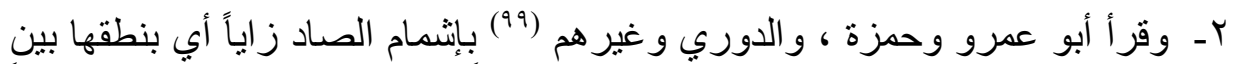

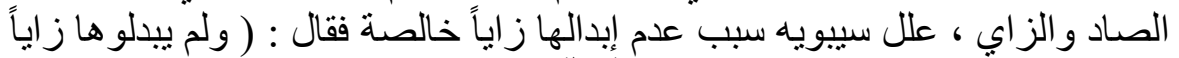
خالصة كر اهيّة الإجحاف بها للإطباق ) ('.").

ووصف هذا الصوت ابن جني فقال : ( الصاد التي كالزاي ، فهي التي يقل همسها قليلاً

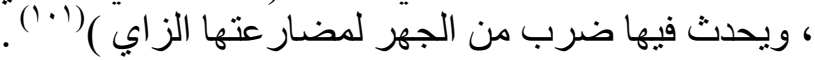

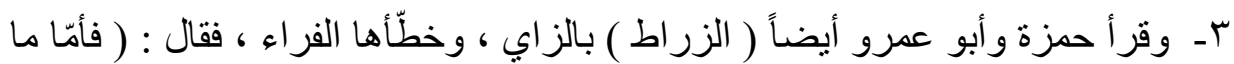

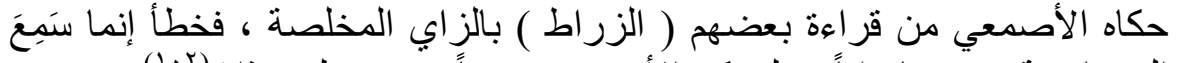

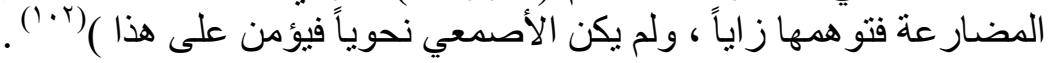

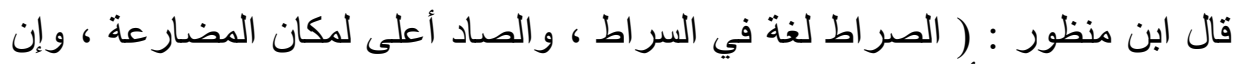

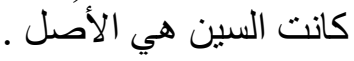

\section{وذكر ابن خالويـه في الحجة قراءاتها على النحو الآتي :}

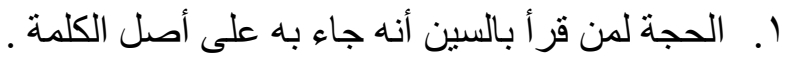

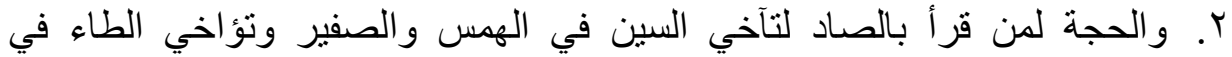

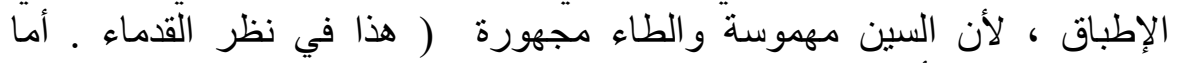

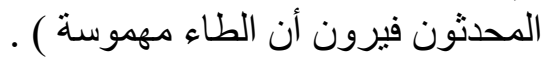

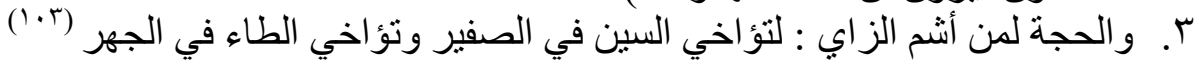

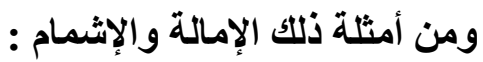
والإشمام : هو نوع من الإمالة ، وسيتضح عند الحديث عنها ، فيما يأتي : الإمالة : والإمام

وتسمى البطح أو الإضجاع أو اللّي ، ويكاد يتفق القدماء على تعريفها تعريفاً يحمل

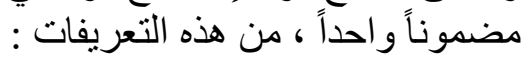

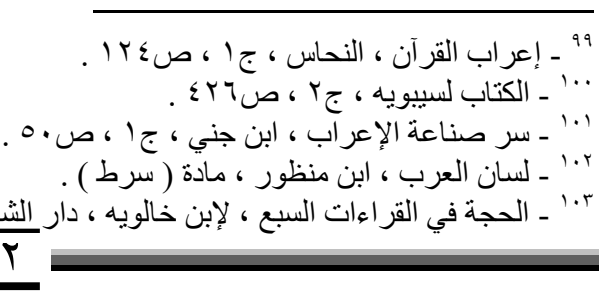




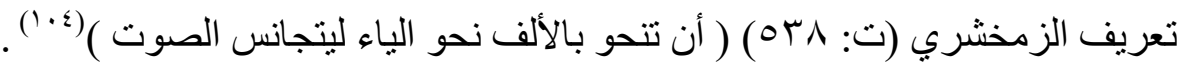

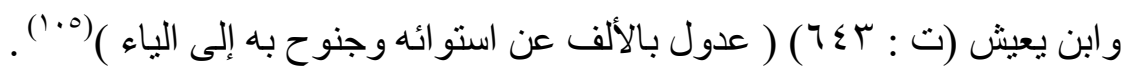

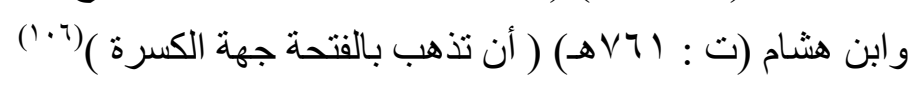

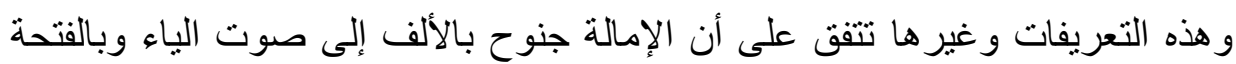

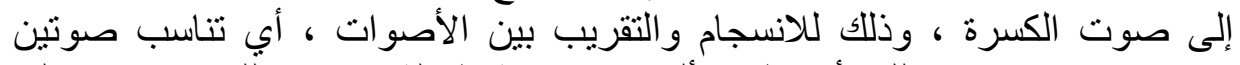

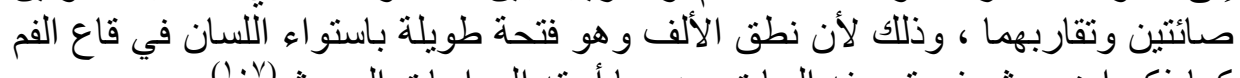

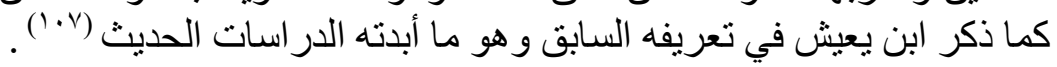

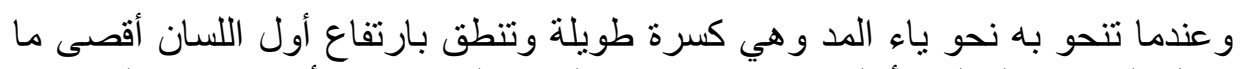

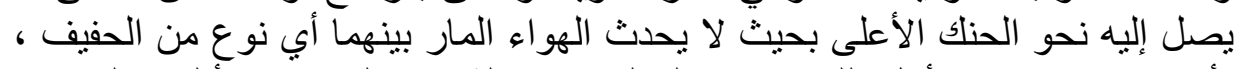

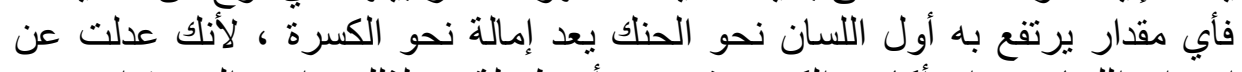

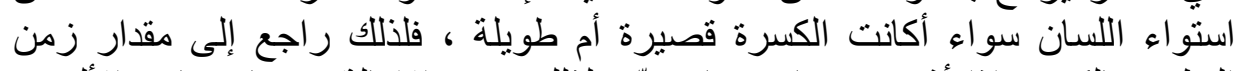

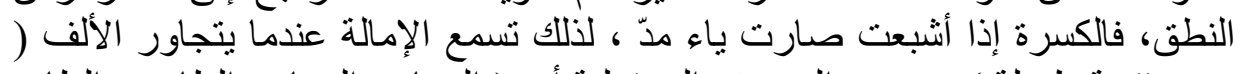

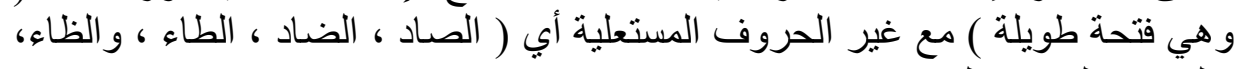
و العين، و الخاء، و الغين) .

وذلك لأن نطق الكسرة يحتاج إلى ارتفاع مقدمة اللسان و هذا يعني أن تتحو بالقتحة

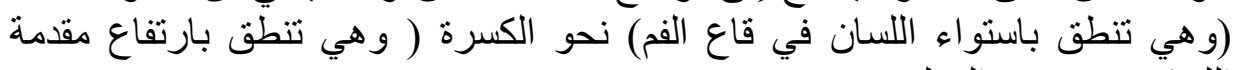

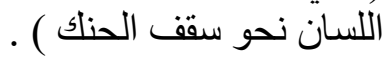

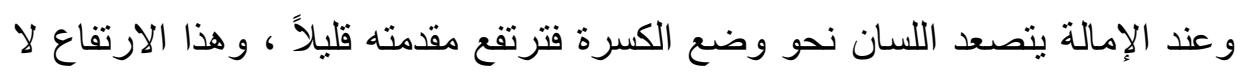

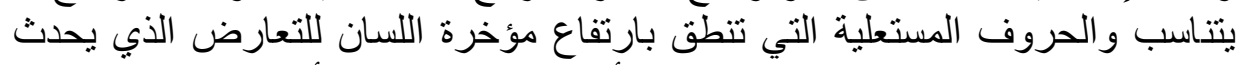

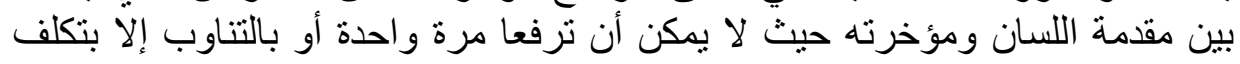

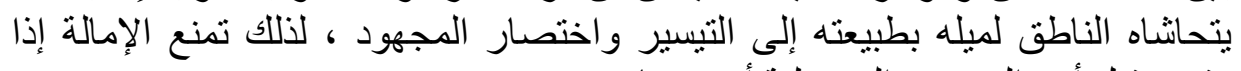

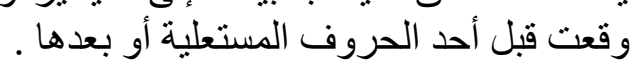

\section{وقد نبّه سيبويه على منع حدوث الإمالة مع الحروف المستعلية فقال :}

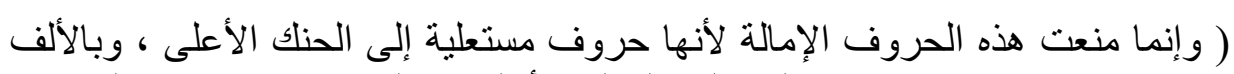

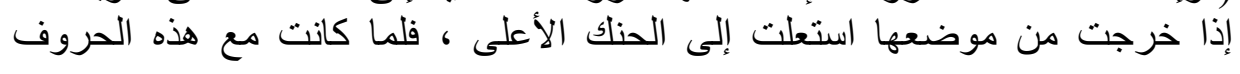

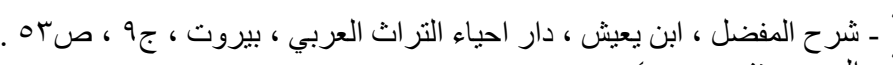

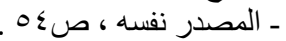

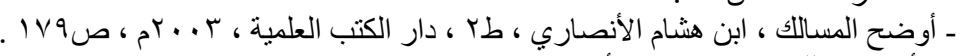




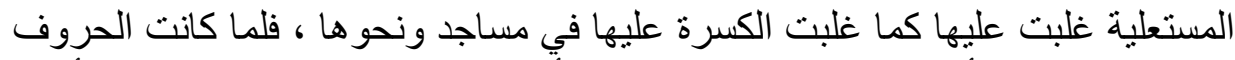

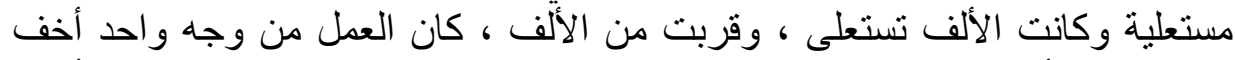

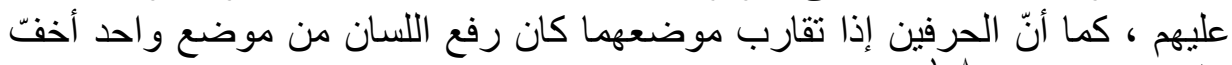

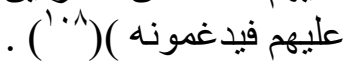

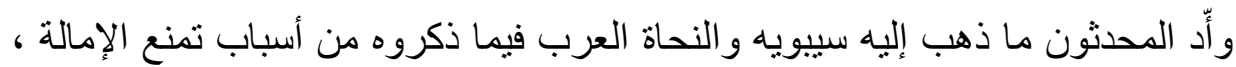

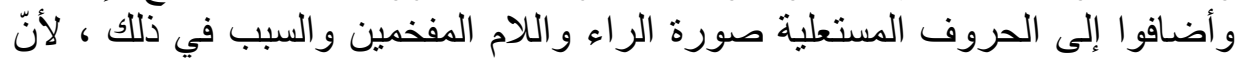

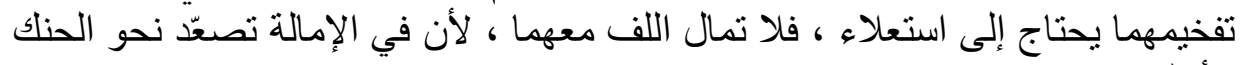

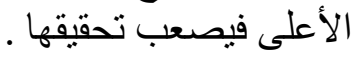

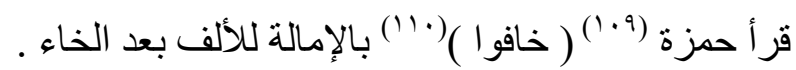

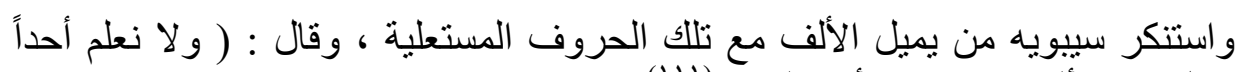
يميل هذه الألف إلا من لا يأخذ بلغته )('l').

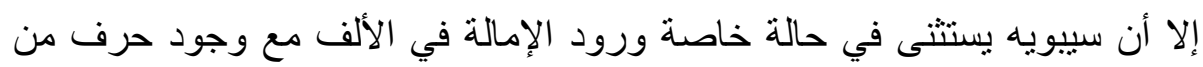

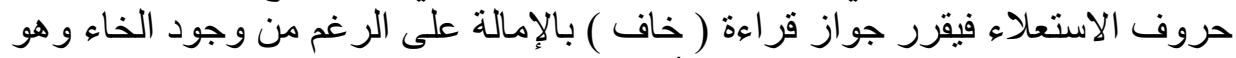

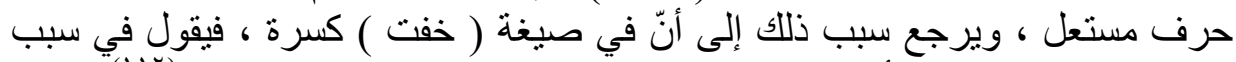

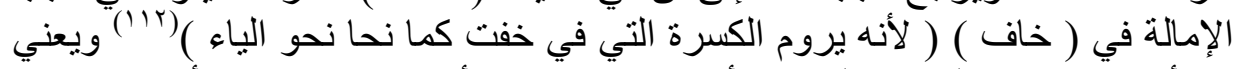

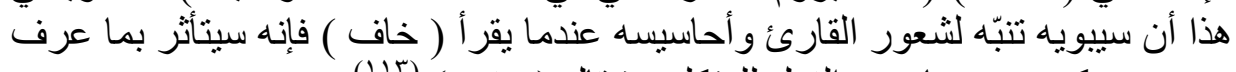

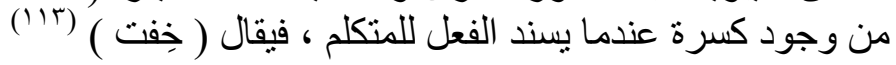

$$
\begin{aligned}
& \text { وقد وردة عدة قراءات بإمالة الألف مع تجاور أحد حروف الحلق نحو : }
\end{aligned}
$$

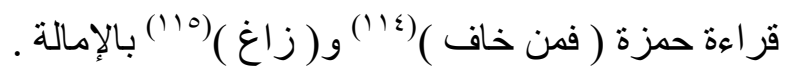

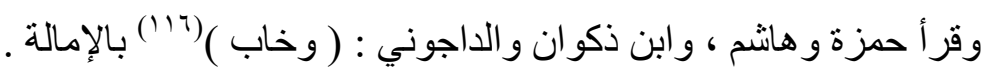

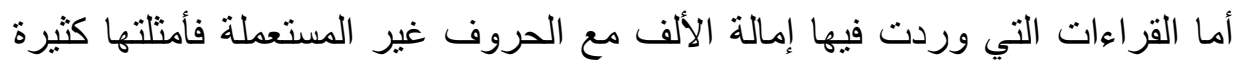

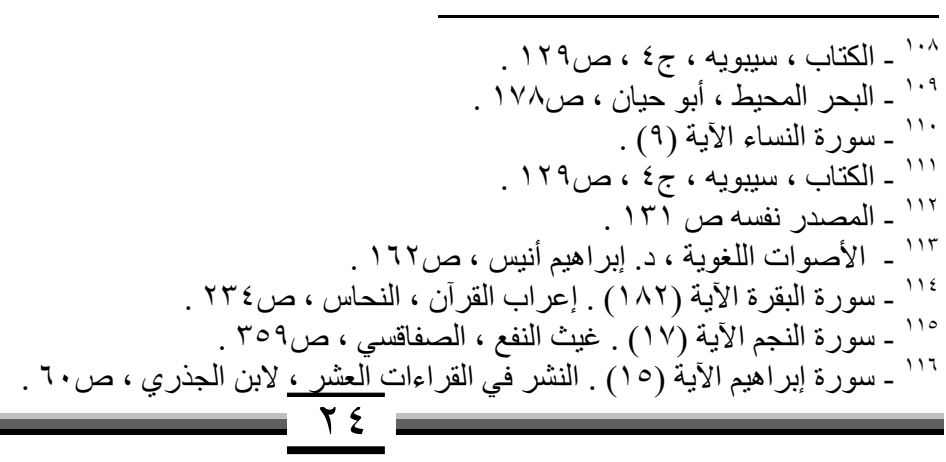




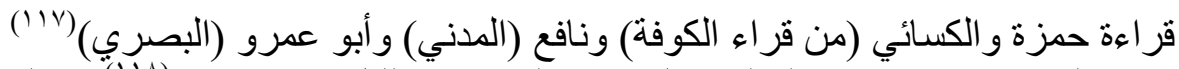

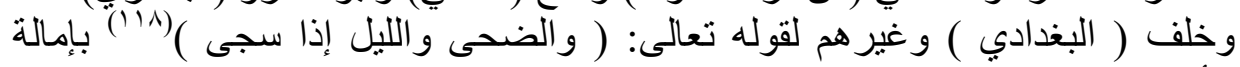
الألف في (الضحى ) نحو الياء. وقرأ بالإمالة أيضا حمزة في: ( جاء ) (19) (1) وقر أ حمزة و الكسائي وخلف ، و وغيره هم

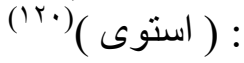

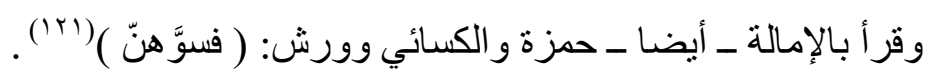

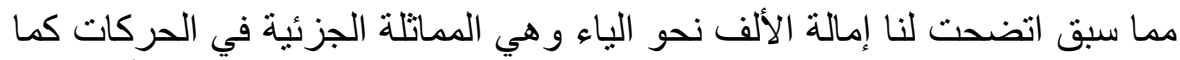

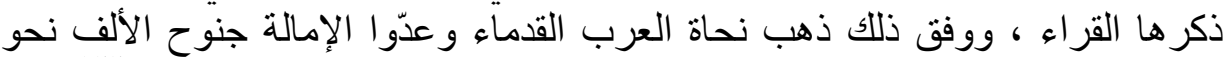

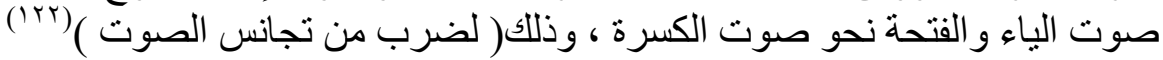

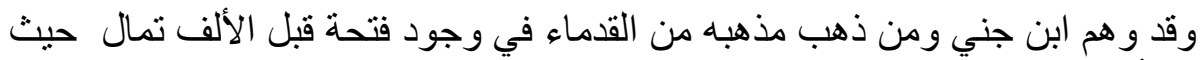

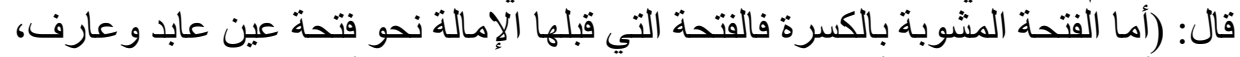

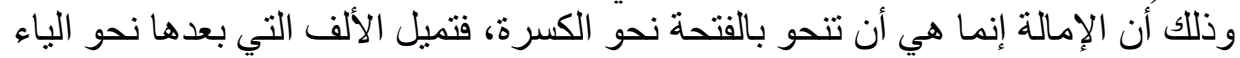

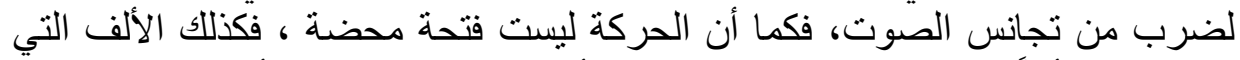

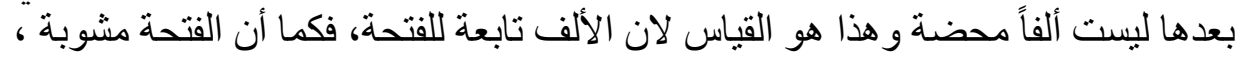
فكذلك الألف اللاحقة لها . لهأ

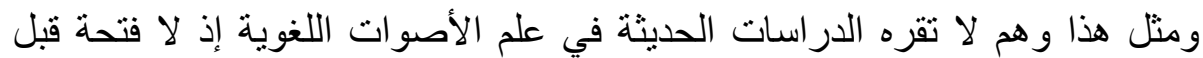

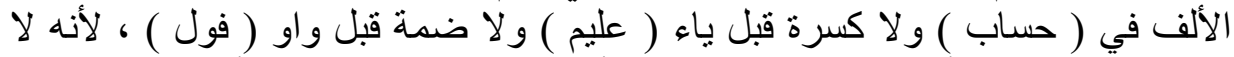

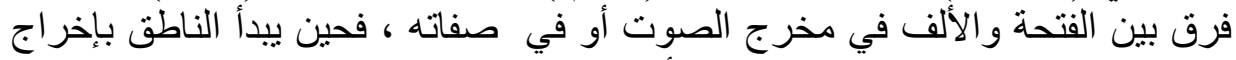

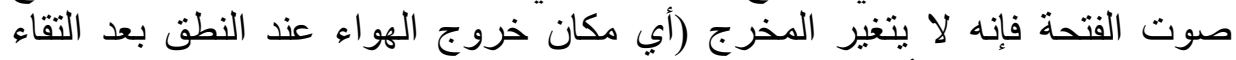

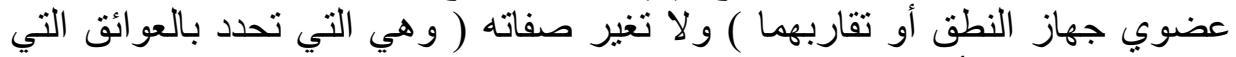

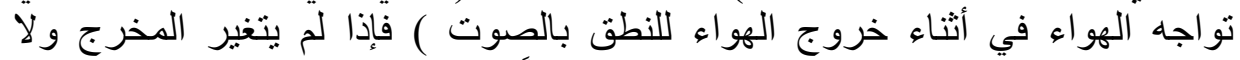

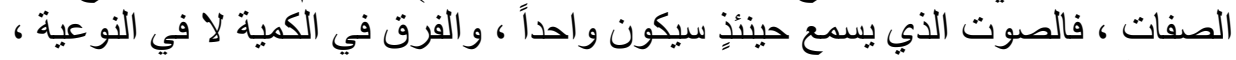

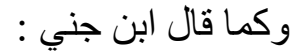

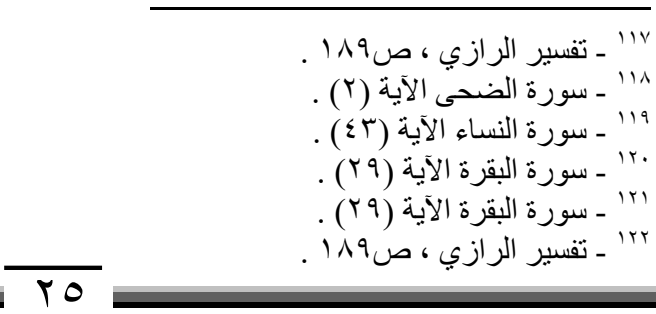




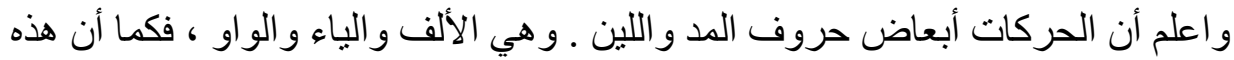

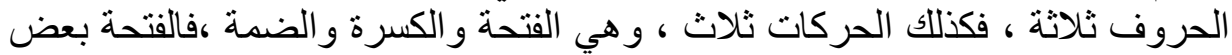

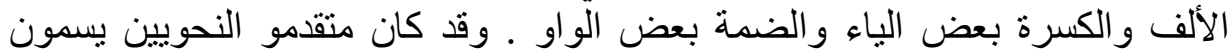

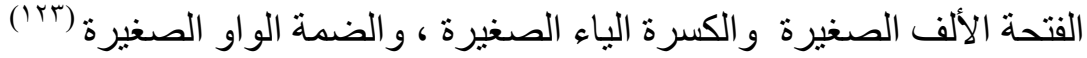

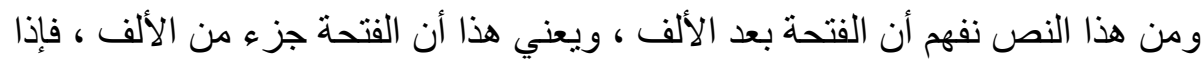

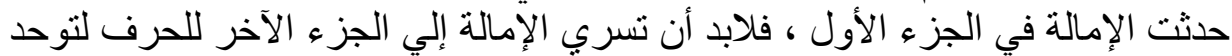
جزئي الألف بالمخرج فئم والصفات .

و على الرغم من شيوع الإمالة في الألف ( الفتحة الطويلة ) نحو الياء ( الكسرة الطويلة ) فإنها تقع أيضاً مع الحركات الأخرى علي النحو الآتي :

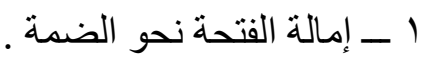

r - إمالة الكسرة نحو الضمة.

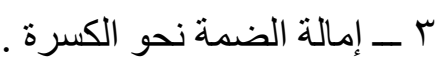
وفيما يأتي توضيح ذلك :

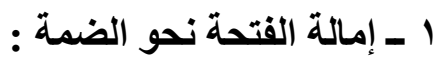

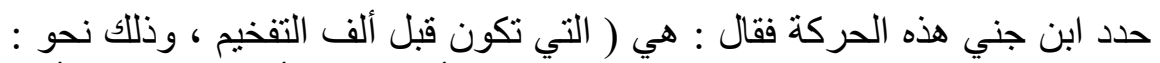

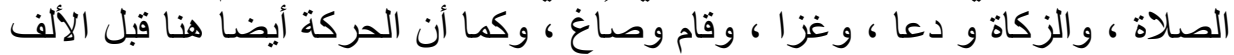

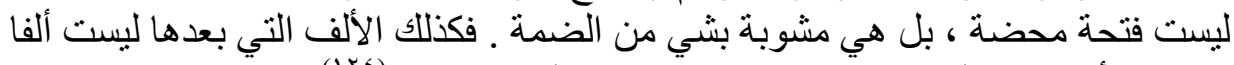

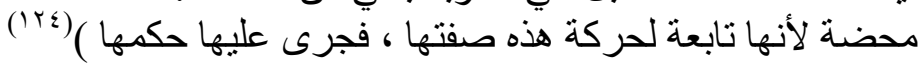

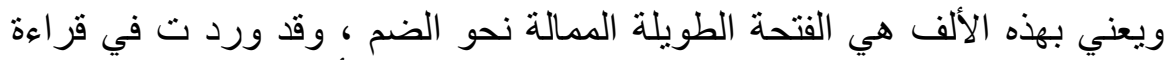

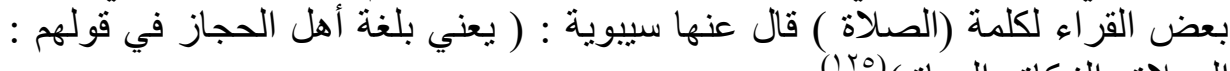

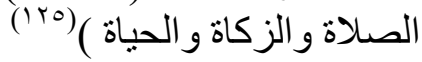

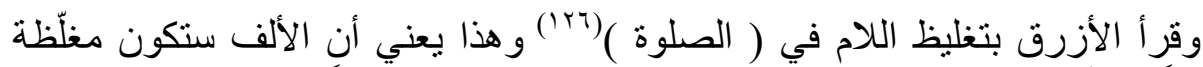

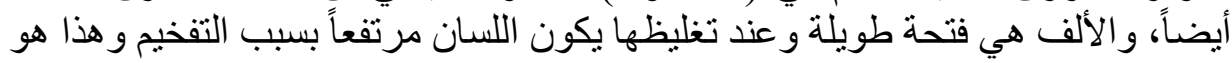

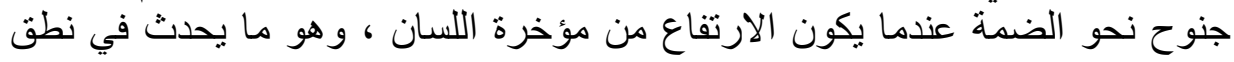

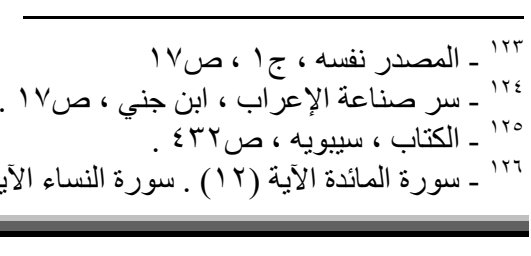




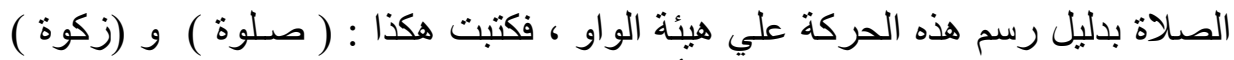

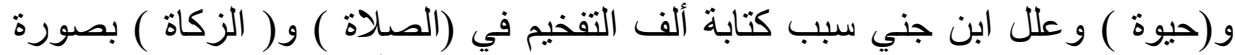

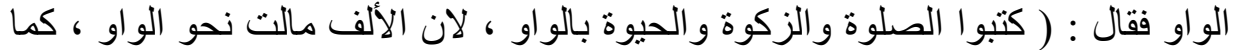

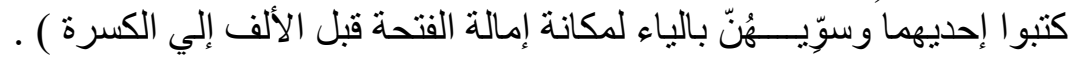

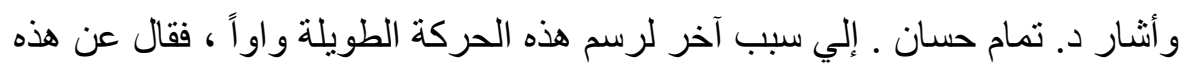

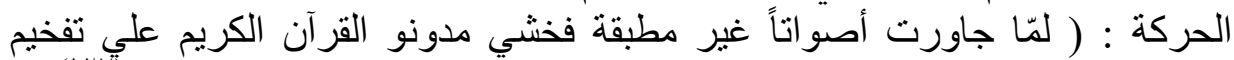

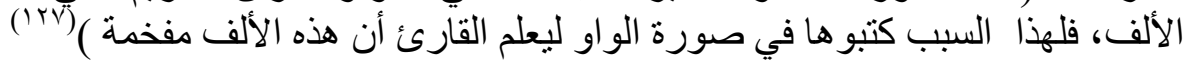

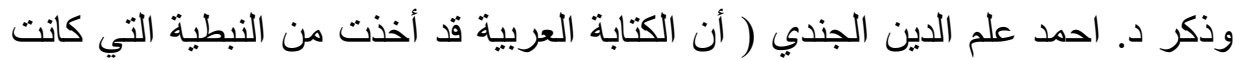

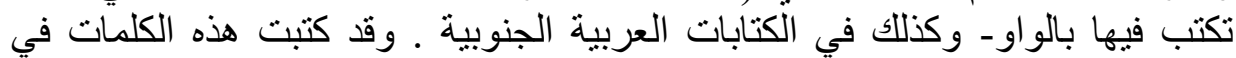

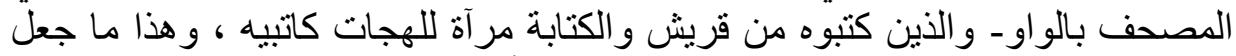

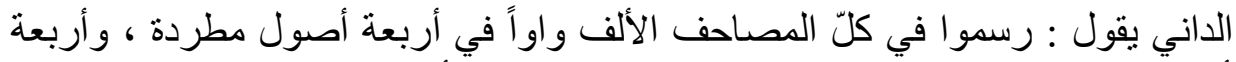

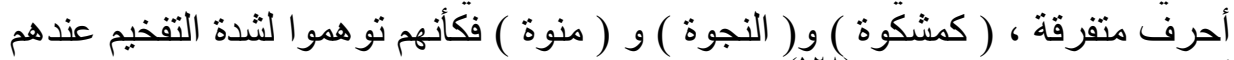

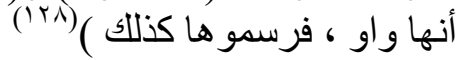

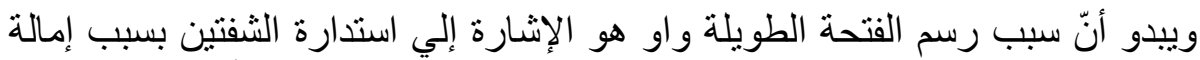

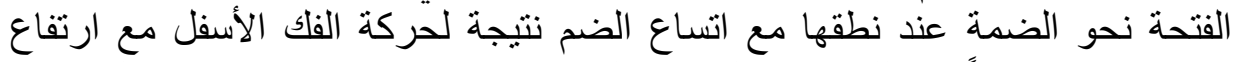

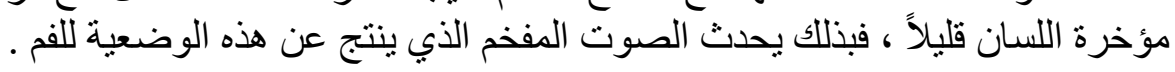

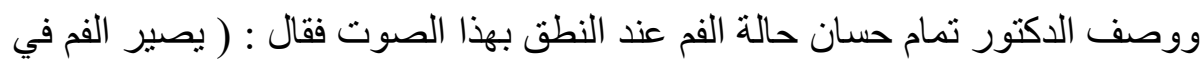

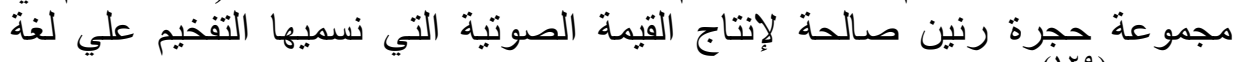

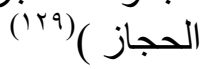

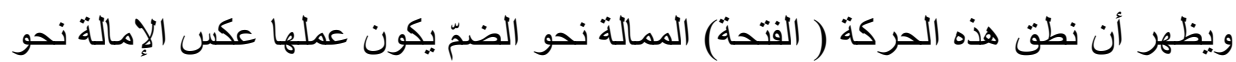

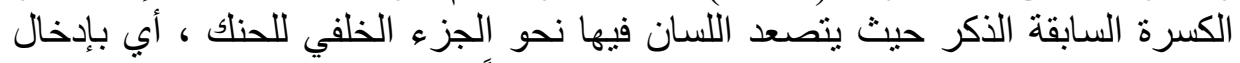

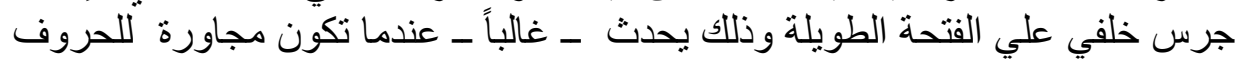
المفخمة المرن

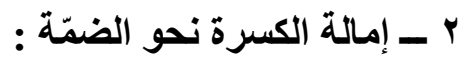

ويسميها القراء و النحاة ( الإشمام ) ، وهي الكسرة المشوبة بالضمة ومثل لها ابن جني

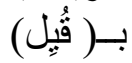

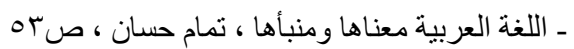

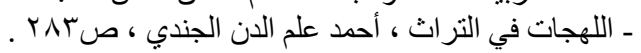

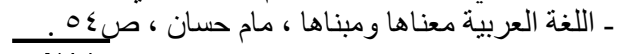


و( بُيع ) و( غُيضِ ) و( سُيِّن ) وأضاف قائلاً : ( وكما أن الحركة قبل هذه الياء مشوبة

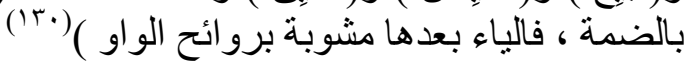

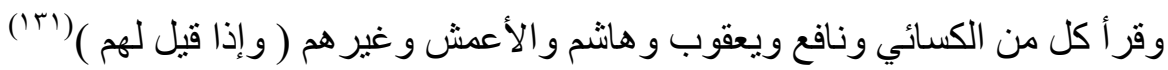
بإثنمام كسرة القاف الضمّ .

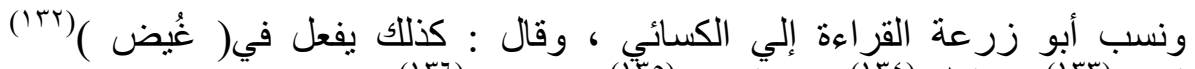

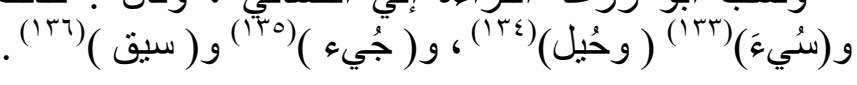

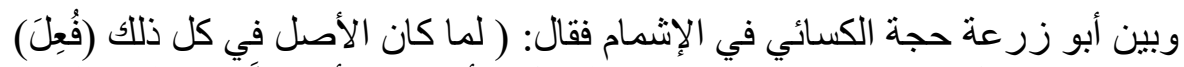

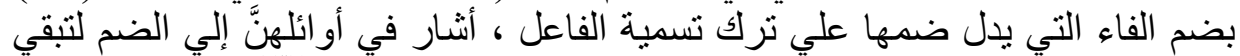

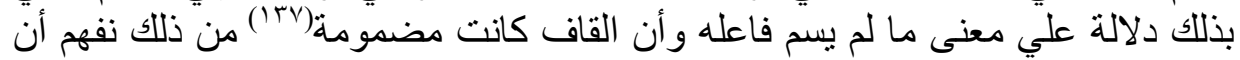

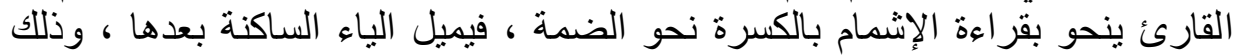

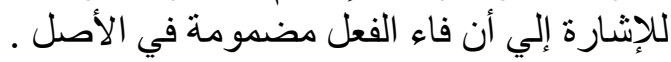

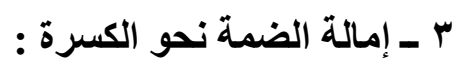

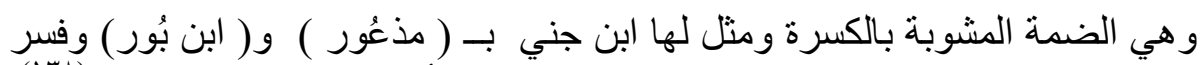

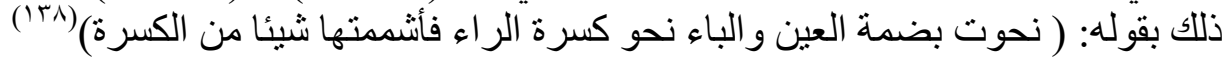
هذه هي الضمّة الممالة نحو الكسرة القصيرة . لمون

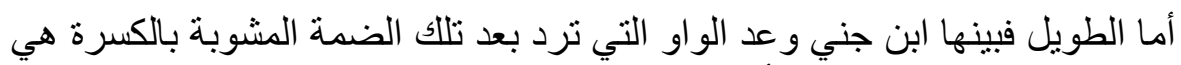

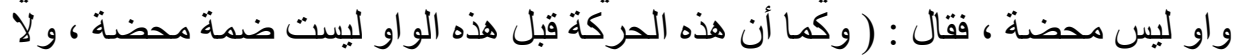

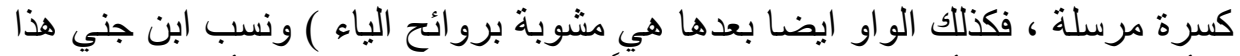

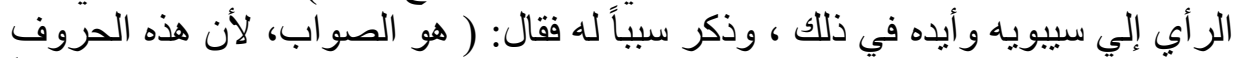

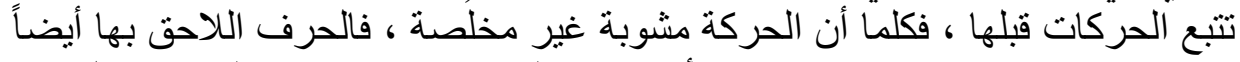

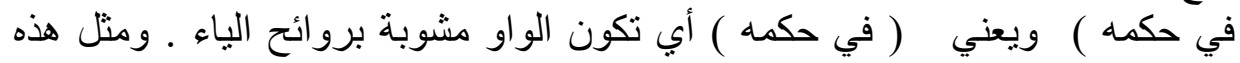

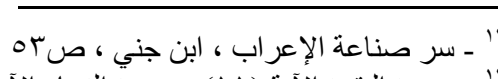

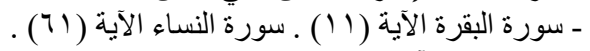
- سورة هود الآية (ع ؟) .

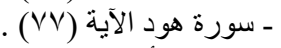

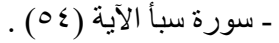
ـ ـ سورة الزمر الآية (79) (79) .

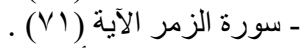

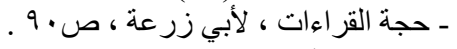




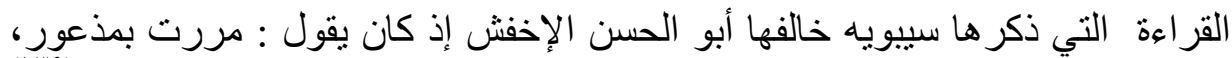

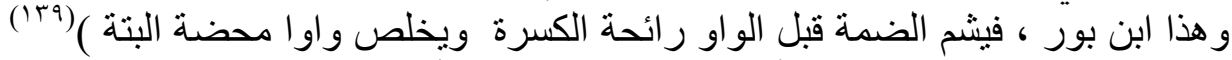

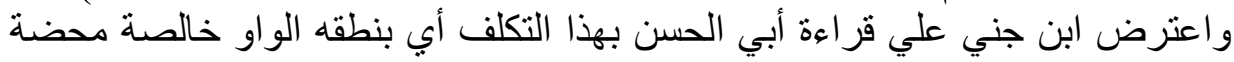

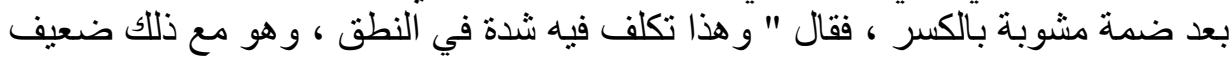

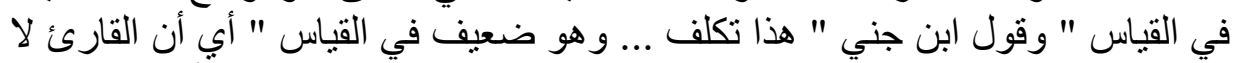

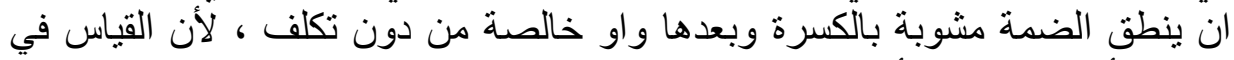

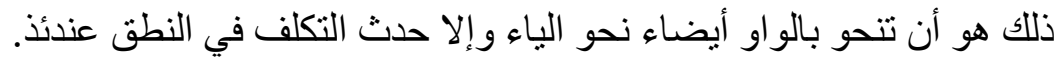

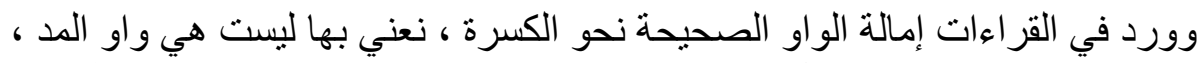

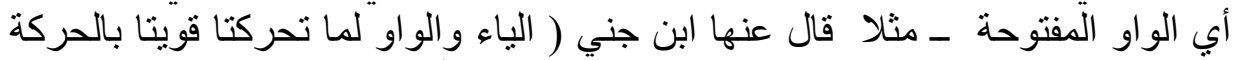

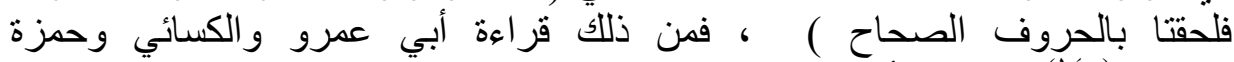

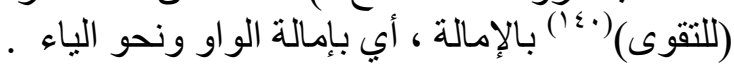

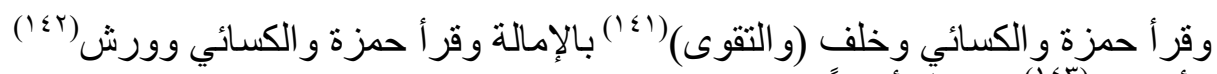

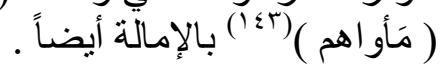

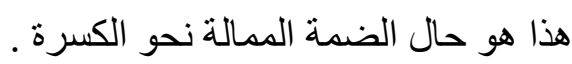
و لا تجد الكسرة و لا الضمة مشوبة بشيء من القتحة ، وسبب ذللك ذكره ابن جني فقال

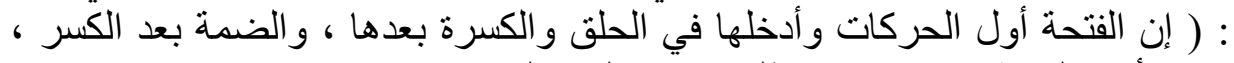

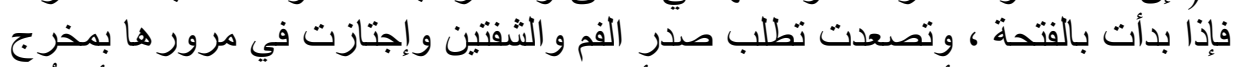

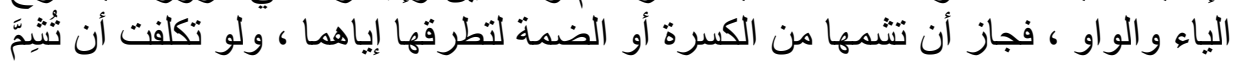

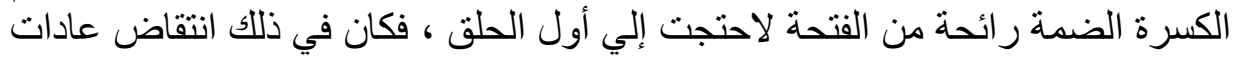

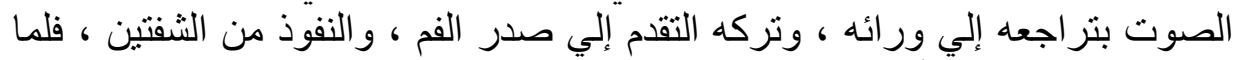

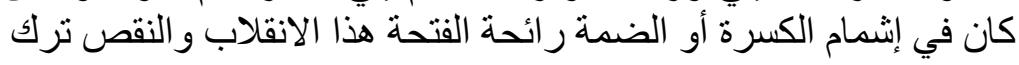

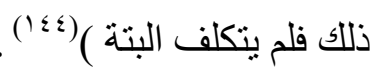
وقال أيضاً : إن بين الضمة و الكسرة من القرب و التناسب ما ليس بينهما وبين الفتحة ،

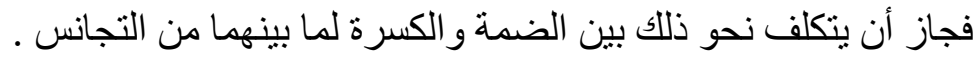

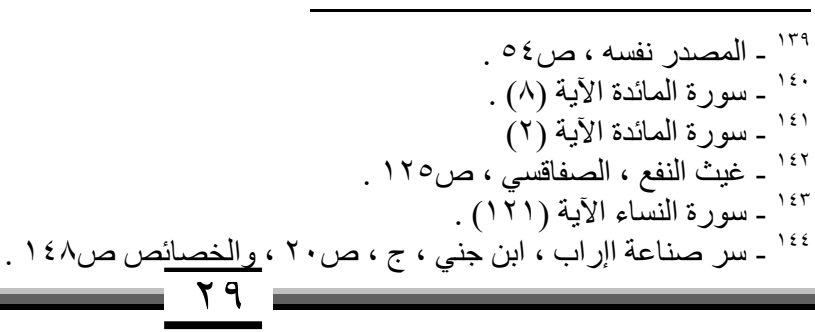


الحمد لله الذي وفقني لكتابة هذا البحث و الذي تباينت فيه الآراء حيث اختلفت وجهة

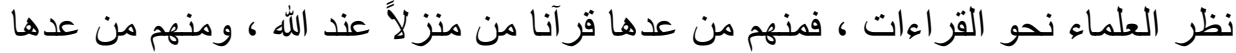

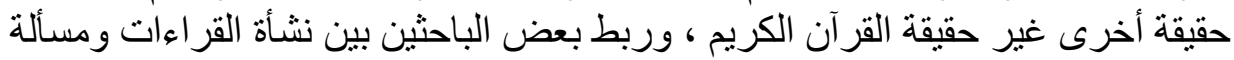

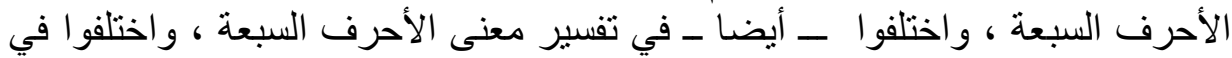

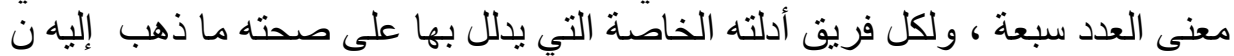

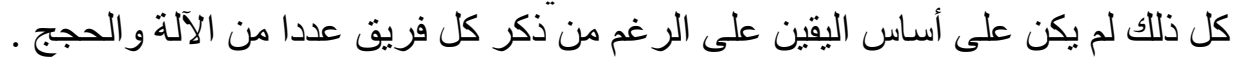

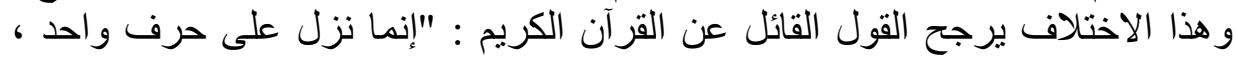
و إن اختلاف قد جاء من الرجن الرواة ".

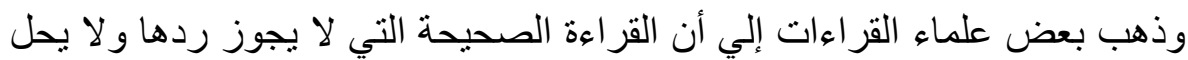

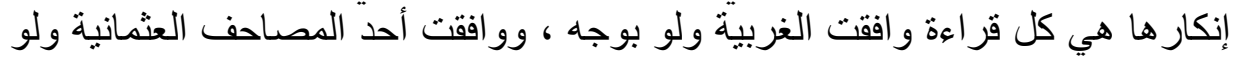

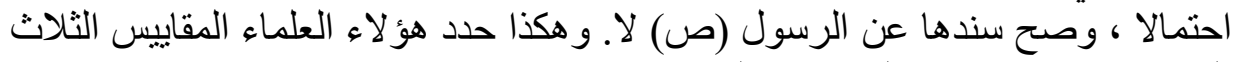

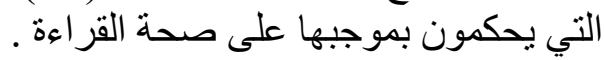

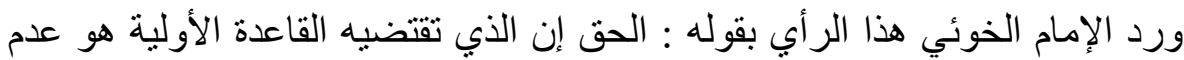

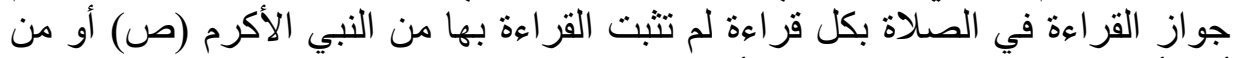

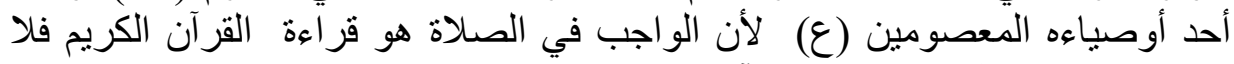

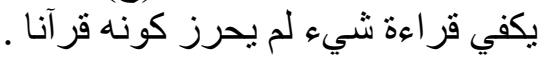

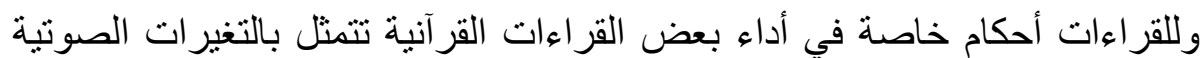

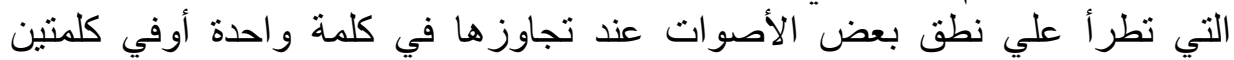

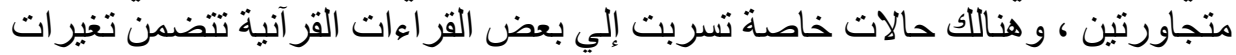

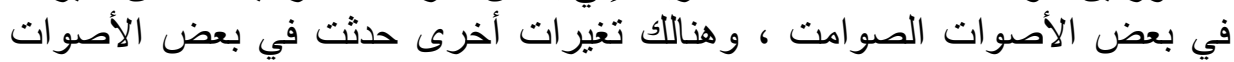

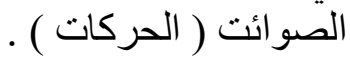

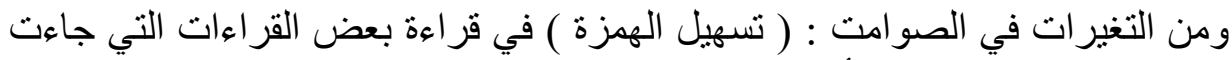

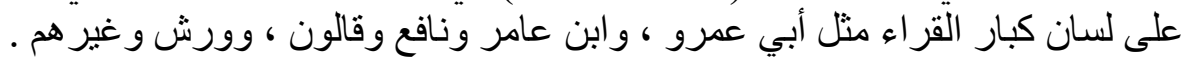

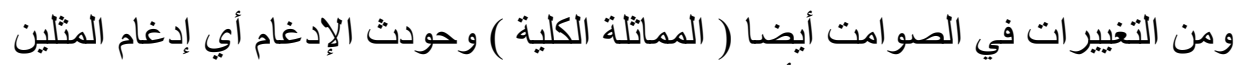

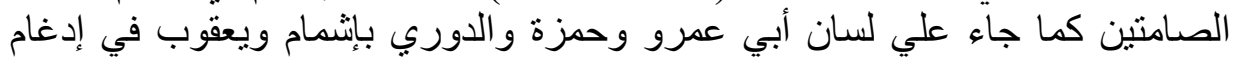

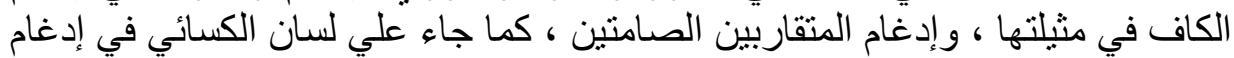

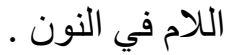

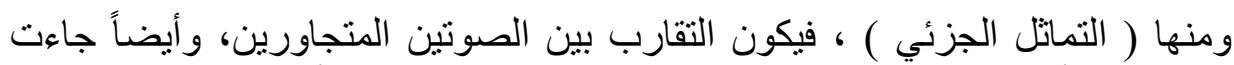

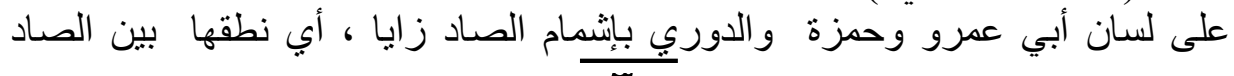




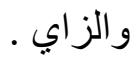

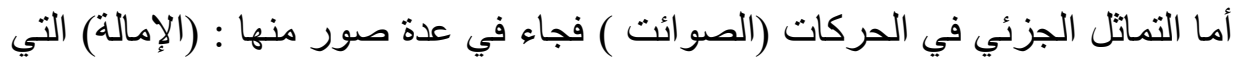

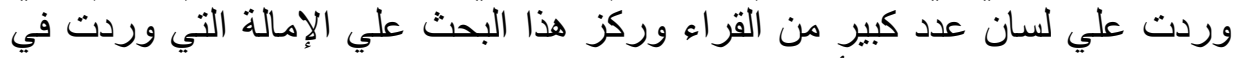

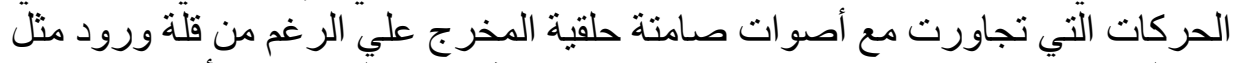

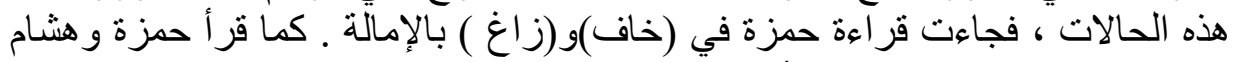

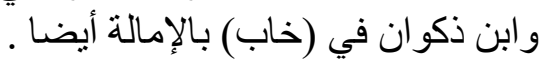

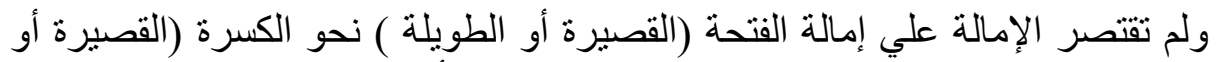

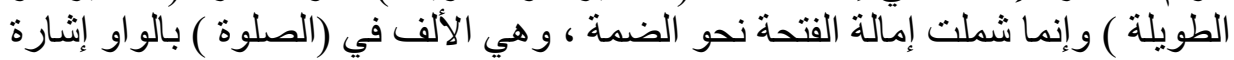
إلي ضم الثفتين. وشملت إمالة الكسرة نحو الفتحة ويسميها القر اء و النحاة بـ (الإشمام ) و وهي الكسرة

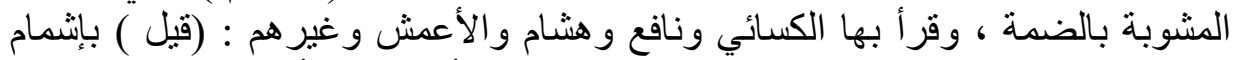

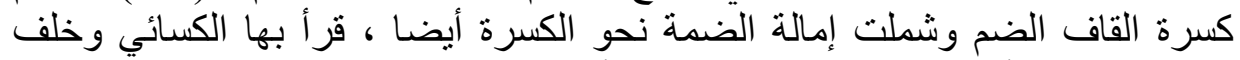
"بالإمالة كما قر أ حمزة و الكسائي وورش المالة الضمة (مأوهم ) بالإمالة .

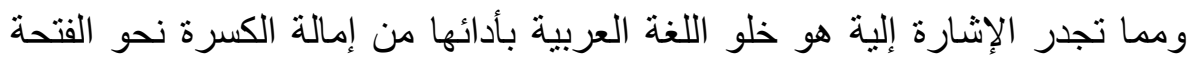

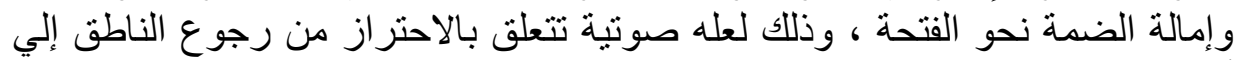

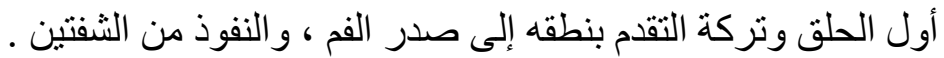


r- البيان في تفسير القرآن ، أبو القاسم الموسوي الخوي ، ط • بـ ، مؤسسة إحياء ، إيران.

r- ـ ورد المثال في غيث النفع في القراءات السبع ، للصفاقسي

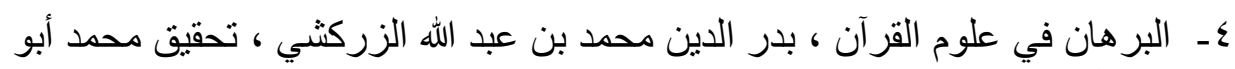
الفضل .

๑ـ نكت الانتصـار لنقل القرآن ، أبو بكر محمد بن الطيب ، تحقيق محمد زغلول ، دار

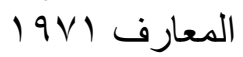

جـ تاريخ القرآن ، د. محمد حسين الصغير ، الدار العالمية ، ط الأولى ، بيروت

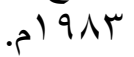

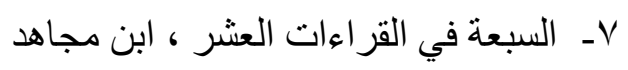

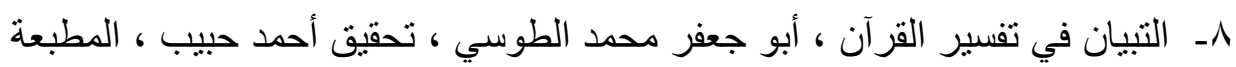

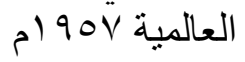

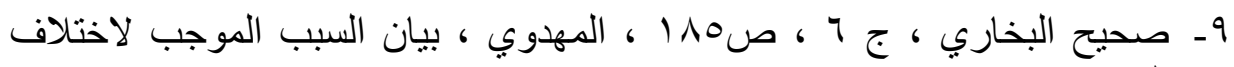
القراءات.

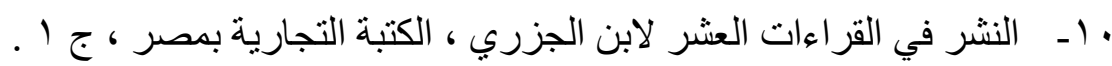

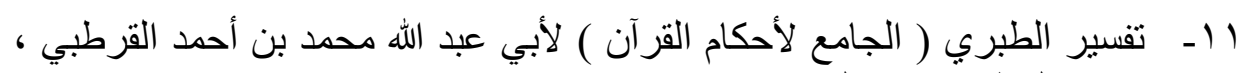

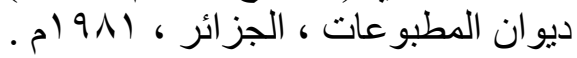

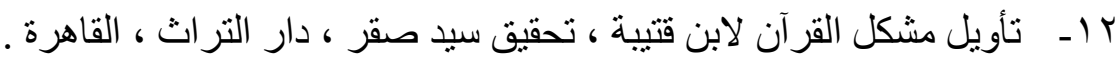

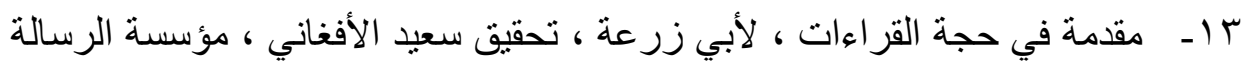

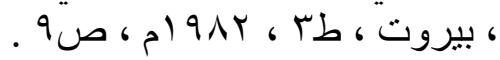

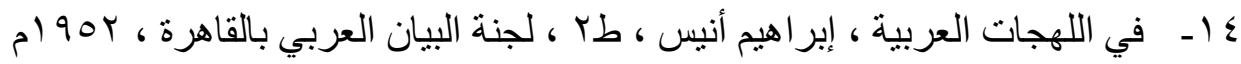

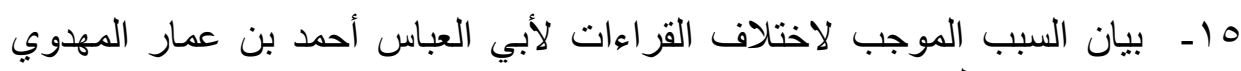

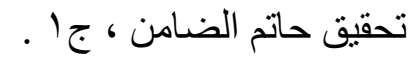

17 - المحتسب لابي الفتح عثمان ابن جني ، تحقيق عبد الخالق عضيمة ، عالم الكتب ، 


$$
\text { بيروت . }
$$

IV - حجة القراءات ، لأبي زرعة ، تحقيق سعيد الأفغاني ، المقدمة .

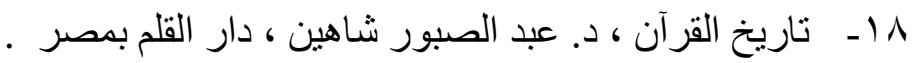

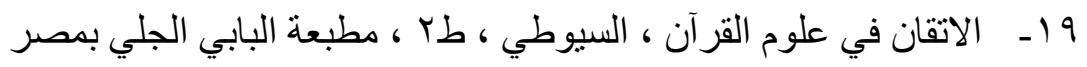

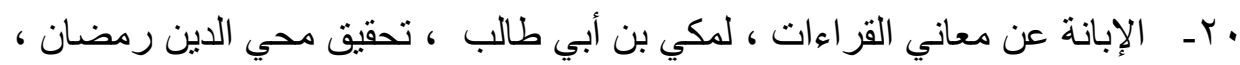

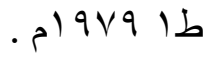

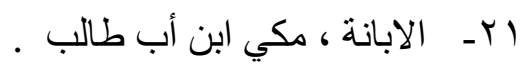

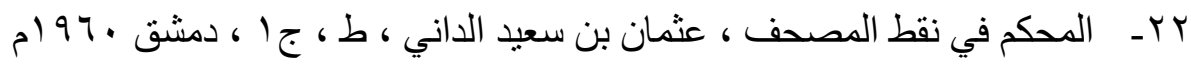

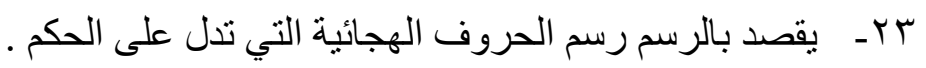

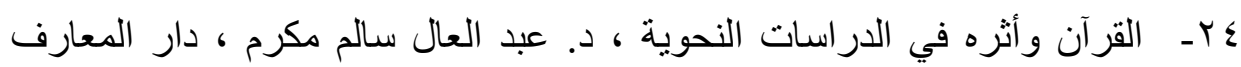

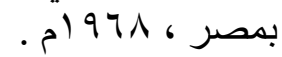
هץ- اللهجات العربية ، ابر اهيم أنيس .

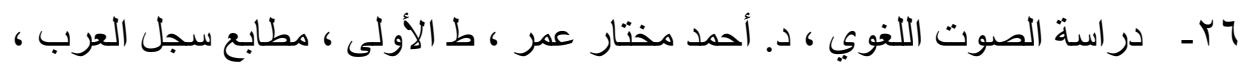

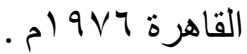

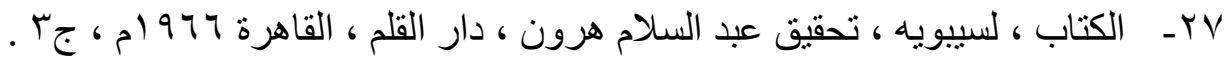

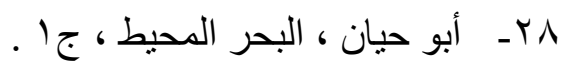

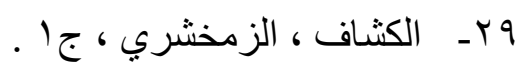
• r- البناء ، إتحاف فضلاء البشر - أحمد بن محمد الدمياط.

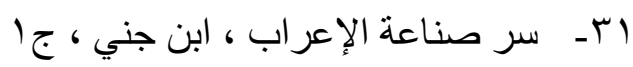

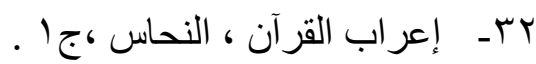

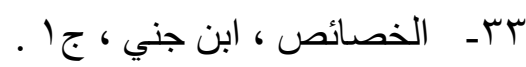

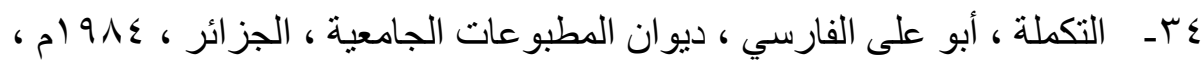

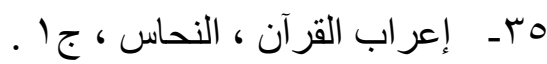

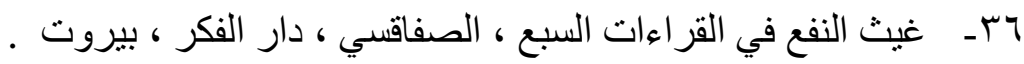
rT 
مrV

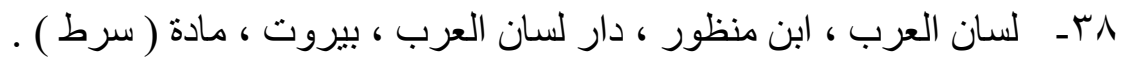

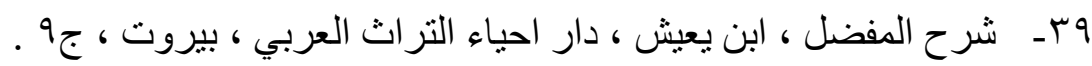

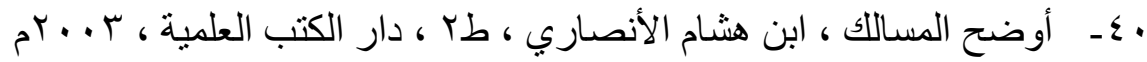
إعـ اللغة العربية معناها ومبناها ، تمام حسان. 